medRxiv preprint doi: https://doi.org/10.1101/2020.11.12.20214478; this version posted August 16, 2021. The copyright holder for this preprint (which was not certified by peer review) is the author/funder, who has granted medRxiv a license to display the preprint in perpetuity.

It is made available under a CC-BY-NC-ND 4.0 International license.

\title{
Upper Limb Motor Improvement after TBI: Systematic Review of Interventions
}

Sandeep K. Subramanian, PhD, ${ }^{1,2,3}$ Melinda A. Fountain, DPT ${ }^{1}$, Ashley F. Hood, DPT ${ }^{1}$ and

Monica Verduzco-Gutierrez, MD ${ }^{2,3}$

Affiliations:

${ }^{1}$ Department of Physical Therapy, School of Health Professions, UT Health San Antonio, San

Antonio, TX, USA

${ }^{2}$ Department of Rehabilitation Medicine, Joe R. \& Teresa Lozano Long School of Medicine, UT

Health San Antonio, San Antonio, TX, USA.

${ }^{3}$ University Hospital-University Health System, San Antonio, TX, USA.

\section{Corresponding Author:}

Sandeep K Subramanian, Ph.D, B.P.Th,

Assistant Professor,

Department of Physical Therapy,

School of Health Professions,

UT Health San Antonio,

San Antonio, Texas,

USA 78229

Phone: 1-210-567-8762

Fax: 1-210-567-8774

Email: subramanias3@uthscsa.edu 
medRxiv preprint doi: https://doi.org/10.1101/2020.11.12.20214478; this version posted August 16, 2021. The copyright holder for this preprint (which was not certified by peer review) is the author/funder, who has granted medRxiv a license to display the preprint in perpetuity.

It is made available under a CC-BY-NC-ND 4.0 International license.

Subramanian et al

TBI upper limb motor improvement review

Word count: 4486

Figures: 1

Tables: 5

Running Head: TBI upper limb motor improvement review 


\begin{abstract}
:
Background: Traumatic Brain Injury (TBI) is a leading cause of adult morbidity and mortality. Individuals with TBI have impairments in both cognitive and motor domains. Motor improvements post-TBI are attributable to adaptive neuroplasticity and motor learning. Majority of the studies focus on remediation of balance and mobility issues. There is limited understanding on the use of interventions for upper limb (UL) motor improvements in this population.
\end{abstract}

Objective: We examined the evidence regarding the effectiveness of different interventions to augment UL motor improvement after a TBI.

Methods: We systematically examined the evidence published in English from 1990-2020. The modified Downs and Black checklist helped assess study quality (total score:28). Studies were classified as excellent:24-28, good:19-23, fair:14-18 and poor: $\leq 13$ in quality. Effect sizes helped quantify intervention effectiveness.

Results: Twenty-three studies were retrieved. Study quality was excellent(n=1), $\operatorname{good}(n=5)$ or fair $(n=17)$. Interventions used included strategies to decrease muscle tone $(n=6)$, constraint induced movement therapy $(n=4)$, virtual reality gaming $(n=5)$, noninvasive stimulation $(n=3)$, arm motor ability training $(\mathrm{n}=1)$, stem-cell transplant $(\mathrm{n}=1)$; task-oriented training $(\mathrm{n}=2)$ and feedback provision $(n=1)$. Motor impairment outcomes included Fugl-Meyer Assessment, Modified Ashworth Scale, and kinematic outcomes (error and movement straightness). Activity limitation outcomes included Wolf Motor Function Test and Motor Activity Log. Effect sizes for majority of the interventions ranged from medium(0.5-0.79) to large $(\geq 0.8)$. Only ten studies included retention testing. 
medRxiv preprint doi: https://doi.org/10.1101/2020.11.12.20214478; this version posted August 16, 2021. The copyright holder for this preprint (which was not certified by peer review) is the author/funder, who has granted medRxiv a license to display the preprint in perpetuity. It is made available under a CC-BY-NC-ND 4.0 International license.

Subramanian et al

TBI upper limb motor improvement review

Conclusion: There is preliminary evidence that using some interventions may enhance UL

motor improvement after a TBI. Answers to emergent questions can help select the most appropriate interventions in this population. 
medRxiv preprint doi: https://doi.org/10.1101/2020.11.12.20214478; this version posted August 16, 2021. The copyright holder for this preprint (which was not certified by peer review) is the author/funder, who has granted medRxiv a license to display the preprint in perpetuity.

It is made available under a CC-BY-NC-ND 4.0 International license .

\section{Introduction}

Traumatic Brain Injury (TBI) is a major worldwide cause of morbidity and mortality. ${ }^{1}$ In the USA, recent reports indicate 2.87 million TBI related visits to the emergency room, ${ }^{2}$ with epidemiological data suggesting males being more affected than females. ${ }^{3}$ Common causes of TBI include falls, motor vehicle accidents and/or assaults. ${ }^{4}$ The available total annual cost estimates for TBI range from $\$ 56-\$ 221$ billion..$^{5}$ Individuals sustaining a TBI may face cognitive ${ }^{6}$ behavioral $^{7}$ and communication difficulties ${ }^{8}$ lasting from few days post-injury to the rest of their lives. ${ }^{9}$ Additionally, a TBI causes sensorimotor impairments to the upper (UL) and lower limbs (LL).

Motor impairments include abnormal posture, altered muscle tone, paresis, reappearance of primitive and tonic reflexes, ataxia, decreased balance, and lack of coordinated movement. ${ }^{10}$ Individuals continue to have limited performance of activities of daily living, especially those relying on coordinated movements and UL muscle strength after a TBI. Persistent UL impairments and limitations in performance of daily life activities impact functional independence in this population. ${ }^{11}$

Motor improvements post-TBI are attributable in part to motor learning and adaptive neuroplasticity. ${ }^{12}$ Provision of rehabilitation benefits motor recovery by focusing on performing accurate repetitions of desired movement, ${ }^{13}$ is an integral part of motor learning and promotes adaptive neuroplasticity. ${ }^{14}$ Recent guidelines stress application of task-specific and intensive repetitive practice of functional reaching and activities including fine motor coordination. ${ }^{15}$

There is a need to identify the most effective and pertinent interventions with a focus on remediation of impairments and activity limitations in this population. ${ }^{16}$ To date, research has focused primarily on cognitive impairments and gait limitations, with less focus on UL issues. ${ }^{17,18}$ This is an important topic, given that the UL issues are more diffuse and tend to be 
medRxiv preprint doi: https://doi.org/10.1101/2020.11.12.20214478; this version posted August 16, 2021. The copyright holder for this preprint (which was not certified by peer review) is the author/funder, who has granted medRxiv a license to display the preprint in perpetuity.

It is made available under a CC-BY-NC-ND 4.0 International license .

long standing in individuals post-TBI. ${ }^{19}$ Previous studies have identified deficits in UL

functioning including impaired timing, reduced reach accuracy and grasping ability. ${ }^{20}$ Improving

UL motor functioning helps boost the ability of individuals with TBI to perform activities of daily living such as dress, wash clothes, cook and groom. ${ }^{21}$ Enhanced UL functioning also enables better community reintegration post-TBI. For e.g., improving ability to drive helps commute to work and ability to be competitively employed, volunteer and/or attend school. ${ }^{22,23}$

Our study objective was to systematically review the available literature focusing on rehabilitation of the UL, in individuals sustaining a TBI. Better identification of useful interventions can help select the best options to be used in the clinic and contribute to evidencebased practice. Our question in the Population, Intervention, Comparison and Outcome (PICO) ${ }^{24}$ format was, "In individuals sustaining a TBI, does provision of rehabilitation interventions augment UL motor improvement post-intervention compared to pre-intervention?” Preliminary results have previously appeared as an abstract. ${ }^{25}$

\section{Methods}

Systematic Literature Review

We performed a systematic search of the literature using Medline, Google Scholar, ISI Web of Science, Science Direct, and CINAHL. A Health Sciences Library Liaison helped formulate appropriate search strategies. Keywords and MeSH terms used included "traumatic brain injury”, "head injury”, “concussion", “arm”, "upper limb”, “upper extremity”, “rehabilitation", "intervention", "motor recovery", "impairment”, “activity limitation” and "motor improvement". We used the terms "AND" and "OR" to combine keywords. Searches involved additional limits to restrict the articles to the English language literature published from January 1990 through August 2020, human species, and adult participants. Inclusion criteria 
medRxiv preprint doi: https://doi.org/10.1101/2020.11.12.20214478; this version posted August 16, 2021. The copyright holder for this preprint (which was not certified by peer review) is the author/funder, who has granted medRxiv a license to display the preprint in perpetuity.

It is made available under a CC-BY-NC-ND 4.0 International license.

were i) exposure to or provision of rehabilitation interventions and ii) assessment of motor impairment and/or limitations in activities of daily living using the UL. Exclusion criteria were i) studies focusing on effects of provision of only cognitive rehabilitation; ii) rehabilitation focusing exclusively on LL outcomes or iii) review articles, single case studies and expert opinion articles. We reviewed the reference lists of retrieved studies to identify additional relevant citations. We also checked the excluded reviews to identify any pertinent citations.

\section{Data Abstraction and Analysis}

Retrieved articles were grouped according to the intervention used. We developed a data abstraction form to extract data from the selected articles. Data were initially extracted by MKF and $\mathrm{AFH}$. The first author (SKS) then verified that all relevant data were obtained from the selected articles. The extracted data included details about chronicity, type of UL intervention, outcome of intervention and results of the study.

We quantified the effectiveness of interventions using estimates of effect sizes. ${ }^{26}$ When pre, post and retentions scores were available, effect sizes were calculated as the mean post-

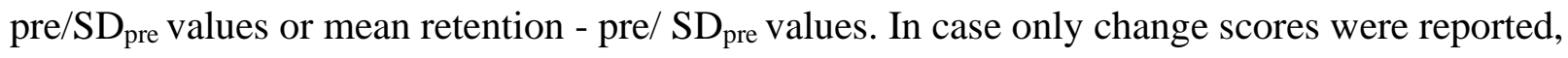
we used the ratio of the mean change score to the variability in change scores. Effect sizes (ES) ranging from $0.2-0.49,0.5-0.79$ and $\geq 0.8$ were interpreted as small, medium, and large, respectively. ${ }^{27}$ We assessed the quality of the selected articles using the modified version ${ }^{28}$ of the Downs and Black checklist. ${ }^{29}$

The Downs and Black checklist is a reliable and valid assessment. ${ }^{30}$ It can be used to assess the quality of both randomized and non-randomized study designs. The total scores of this assessment and PEDro scale are highly correlated in studies involving individuals with brain injuries. ${ }^{31,32}$ Scores on the Modified Downs and Black checklist were rated as "excellent" (score 
medRxiv preprint doi: https://doi.org/10.1101/2020.11.12.20214478; this version posted August 16, 2021. The copyright holder for this preprint (which was not certified by peer review) is the author/funder, who has granted medRxiv a license to display the preprint in perpetuity.

It is made available under a CC-BY-NC-ND 4.0 International license .

24-28), "good" (score 19-23), "fair" (score 14-18), or "poor" (score $\leq 13$ ). ${ }^{33}$ The quality of each study was independently evaluated by AFH and MKF, with discrepancies, if any, resolved by SKS.

\section{Results}

A total of 140 citations were identified through database searches (Figure 1). After removing duplicates, 120 citations were screened, of which 90 were excluded. Of the 30 full text articles assessed for eligibility, we excluded seven studies, as they were reviews and/or expert opinions. Twenty-three articles were included in the qualitative synthesis. The different interventions used included those to reduce muscle tone $(n=6)$, constraint induced therapy $(n=4)$, virtual reality based gaming $(n=5)$, non-invasive stimulation $(n=3)$ [including neuromuscular electrical stimulation $(n=1)$ and transcranial direct current stimulation $(n=2)]$, Arm Motor Ability training $(n=1)$, use of stem cells $(n=1)$, goal oriented task-specific practice $(n=1)$, feedback provision $(n=1)$ and forced use therapy $(n=1)$. The average $(95 \%$ CI $)$ age of participants was 36.4 (29.1 to 43.6) years. Brief highlights of the studies are presented below, with details in the accompanying tables. The scoring for the modified D\&B checklist for each individual study is available in Supplementary table 1.

\section{Insert_figure_1_near_here}

\section{A. Interventions to reduce muscle tone}

We found six studies (quality ranging from fair to good) that examined the effects of different interventions on UL muscle tone (Table 1). Studies investigated the effects of different 
medRxiv preprint doi: https://doi.org/10.1101/2020.11.12.20214478; this version posted August 16, 2021. The copyright holder for this preprint (which was not certified by peer review) is the author/funder, who has granted medRxiv a license to display the preprint in perpetuity.

It is made available under a CC-BY-NC-ND 4.0 International license .

interventions on muscle tone reduction including provision of Botulinum toxin A injections, oral medication, serial casting soft splinting and acupuncture.

Two studies ${ }^{34,35}$ investigated the effects of Botulinum toxin A injections on wrist flexor muscle tone in 27 individuals post-TBI (18 males, 9 females) with moderate-to-severe muscle tone. Botulinum toxin A injections were delivered to target muscles under EMG guidance. Changes in muscle tone (quantified using Modified Ashworth's Scale) and wrist extension range of motion (measured using goniometry) helped assess the effects of the injections. Muscle tone decreased and wrist extension range increased following Botulinum toxin A injections (ES>0.8).

Meythaler et $\mathrm{al}^{36}$ assessed the effects of oral tizanidine administration on UL muscle tone in 17 individuals (14 males, 3 females) with acquired brain injuries (ABIs; TBI: $n=8$, stroke: $\mathrm{n}=9$ ). They administered either tizanidine or placebo in a crossover fashion for 6 weeks, tapered the drug for one week and then switched over to other medication after one more week. Oral tizanidine decreased muscle tone (assessed using Original Ashworth's scale) on the affected side immediately after treatment $(E S=-0.36)$ with no retention at 6 weeks $(E S=-0.1)$.

Moseley et $\mathrm{al}^{37}$ recruited 26 individuals (23 males, 3 females) post-TBI with elbow flexion contracture, and randomized them into two groups (n=13/group). One group received serial casting, and the other received static positioning. Serial casting increased elbow range by $22^{\circ}$ over static positioning immediately post-intervention $(\mathrm{ES}=1.85)$. One day after cast removal, elbow range gain decreased to $15^{\circ}$ in the serial casting group $(\mathrm{ES}=1.17)$, which further decreased to $11^{\circ}$ after 2 weeks post-intervention.

Thibaut et $\mathrm{al}^{38}$ randomized 17 participants (10 males, 7 females) with ABIs (TBI: $\mathrm{n}=7$, stroke: $\mathrm{n}=10$ ) to receive either soft splinting, 30 minutes of manual stretching, or no treatment. Provision of soft splinting resulted in increased hand opening ability $(2.39 \mathrm{~cm}$ of major-palm 
medRxiv preprint doi: https://doi.org/10.1101/2020.11.12.20214478; this version posted August 16, 2021. The copyright holder for this preprint (which was not certified by peer review) is the author/funder, who has granted medRxiv a license to display the preprint in perpetuity.

It is made available under a CC-BY-NC-ND 4.0 International license .

distance, ES=0.55). Additionally, soft splinting and manual stretching decreased finger flexor muscle tone after 30 minutes of treatment $(E S=-0.53$ and -0.55$)$.

Matsumoto et $\mathrm{al}^{39}$ assessed effects of acupuncture provision on UL muscle tone in 11 unconscious or minimally conscious males. They used a crossover study design providing acupuncture or no treatment, separated by one week. Acupuncture provision reduced the F/M ratio at the end of treatment $(E S=-0.73)$ and was retained 10 minutes later $(E S=-0.7)$.

\author{
Insert_Table_1_here
}

\title{
B. Constraint Induced Movement Therapy (CIMT)
}

We found four studies (fair quality; Table 2) that assessed the effects of CIMT on UL impairment, activity, and self-reported UL use levels. Page and Levine, ${ }^{40}$ in a case series involving three participants ( 2 males, 1 female) post-TBI, constrained the less-affected side (5hours/day; 10 weeks). All participants improved UL activity performance measured using the Wolf Motor Function Test - Functional Ability Scale (WMFT; ES=3.0) and Action Research Arm Test (ES=1.78). Additionally, participants also improved the amount and quality of selfperceived use, assessed using the Motor Activity Log (MAL).

Two studies examined the effects of CIMT on participants with chronic TBI. In both studies, participants wore the mitt on the less-affected limb for $90 \%$ of waking hours. All participants ( $\mathrm{n}=22 ; 14$ males, 8 females) in the first study by Shaw et al ${ }^{41}$ decreased UL motor impairment measured using the Fugl-Meyer Assessment (FMA; ES=1.4) and improved in performance of daily life activities (measured using WMFT; ES=0.7) immediately after treatment. Participants also reported an increase in self-perceived quality of movement 
medRxiv preprint doi: https://doi.org/10.1101/2020.11.12.20214478; this version posted August 16, 2021. The copyright holder for this preprint (which was not certified by peer review) is the author/funder, who has granted medRxiv a license to display the preprint in perpetuity.

It is made available under a CC-BY-NC-ND 4.0 International license .

immediately after the intervention $(\mathrm{ES}=2.1)$, which was retained at one month $(\mathrm{ES}=2.1)$ and at two years post-intervention $(\mathrm{ES}=1.3)$.

Participants in the other study by Morris et al. ${ }^{42}$ ( $\mathrm{n}=29 ; 19$ males, 10 females) similarly had better scores on the FMA $(\mathrm{ES}=1.5)$ and WMFT $(\mathrm{ES}=0.4)$. Participants reported an increase in the amount $(\mathrm{ES}=1.7)$ and quality $(\mathrm{ES}=2.1)$ of self-perceived UL use after the intervention. Participants reporting better use of the more-affected UL had better global cognition (assessed using the Mini-Mental Scale) and visual attention and task switching (measuring using the Trail Making Tests A and B).

Cho et $\mathrm{al}^{43}$ examined the effects of CIMT on fine motor function of the hand in 9 participants ( 8 males, 1 female) with ABIs (TBI: $n=3$, stroke: $n=6$ ). The less-affected side was partially constrained with an opposition restriction splint that blocked use of the thumb and index finger. All participants were evaluated weekly using the Perdue Pegboard test, until no change was seen in three consecutive assessments. Constraining the less-affected side resulted in improved performance on the pegboard test $(\mathrm{ES}=1.31)$.

\author{
Insert_Table_2_here
}

\title{
C. Virtual Reality Gaming
}

We found five studies (fair to good quality; Table 3) that assessed the effects of VR on motor performance outcomes and UL functional outcomes.

In two studies, Ustinova and colleagues examined the effects of task-practice of reaching movements from a standing position. In the first study, ${ }^{44} 13$ participants post-TBI (6 males, 7 females) practiced 10 trials of reaching movements. Movements were recorded using a motion analysis system. At the end of 10 trials, participants reached faster to the targets (ES=0.54), and 
medRxiv preprint doi: https://doi.org/10.1101/2020.11.12.20214478; this version posted August 16, 2021. The copyright holder for this preprint (which was not certified by peer review) is the author/funder, who has granted medRxiv a license to display the preprint in perpetuity. It is made available under a CC-BY-NC-ND 4.0 International license .

further improved $(\mathrm{ES}=0.74)$ at retention testing (30 minutes post-intervention). The participants also had straighter reaching movements $(E S=-1.07)$, which were retained $(E S=-0.97)$.

The second study, ${ }^{45}$ examined the effects of multiple sessions of playing games on balance, reaching and co-ordination. Participants ( $\mathrm{n}=15 ; 10$ males, 5 females $)$ with chronic TBI played games for 15 sessions (thrice weekly). All participants were assessed at baseline, after practice and one-month post-practice. Dynamic balance $(\mathrm{ES}=1.33)$ and reaching movement straightness $(E S=-1.16)$ improved after practice and at one month, these changes were retained. Mumford et $\mathrm{al}^{46}$ examined the effects of repetitive practice of unimanual and bimanual UL movements in nine individuals (5 males, 4 females) with severe chronic TBI. Assessments included kinematic measures of reaching as well as the number of blocks transferred on the Box and Blocks Test (BBT). After training, all participants had more accurate movements $(\mathrm{ES}=0.62)$ and transferred more blocks $(\mathrm{ES}=0.42)$.

Syed and $\mathrm{Kamal}^{47}$ assessed the effects of VR-based gaming on 34 individuals with a variety of neurological disorders (26 males, 8 females) including TBIs (n=9). Participants received 12 sessions of either VR-based training $(n=17)$ or conventional training $(n=17)$. Both groups improved after training with greater changes noted with VR-based $(\mathrm{p}<0.001)$ compared to conventional training $(\mathrm{p}<0.05)$ for both balance (assessed using Berg Balance Scale, BBS) and self-reported UL ADL performance [assessed using Disabilities of the Arm, Shoulder and Hand (DASH) questionnaire). When results were compared only for the participants post-TBI, greater within group changes were noted after VR-based training compared to before for BBS (ES=5.73) and DASH (ES=2.35).

In another study, Buccellato et $\mathrm{al}^{48}$ examined the effects of VR-based gaming on a group of 21 participants ( 15 males, 6 females) with ABIs (TBI: $n=13$, stroke: $n=4$, a combination of stroke + TBI: $n=4)$. Participants were randomized to an early treatment group $(n=11)$ or a 
medRxiv preprint doi: https://doi.org/10.1101/2020.11.12.20214478; this version posted August 16, 2021. The copyright holder for this preprint (which was not certified by peer review) is the author/funder, who has granted medRxiv a license to display the preprint in perpetuity.

It is made available under a CC-BY-NC-ND 4.0 International license .

delayed treatment group (began training 3 weeks after study initiation; $n=10$ ). The effects of this system on UL function, dexterity and activity performance was assessed using the FMA, BBT and Jebsen Taylor Hand Function test, respectively. Early or delayed training did not result in improved function or dexterity. However, activity performance was improved $(\mathrm{ES}=0.52)$.

Insert_Table_3_here

\section{Non-invasive Stimulation}

We found 3 studies (fair quality) that assessed the effects of non-invasive stimulation including use of neuromuscular electrical stimulation (NMES; one study; Table 4A) and transcranial direct current stimulation (tDCS; two studies; Table 4B) on UL motor improvement after TBI.

Alon et $\mathrm{al}^{49}$ assessed the effects of provision of NMES enabling reciprocal finger flexion and extension along with grasp and release in 20 individuals (14 males, 6 females) with chronic ABIs (TBI: $n=7$, stroke: $n=13$ ). All participants received an average of 3.5 hrs. stimulation daily over the course of the intervention, which lasted for almost 4 months. All participants had a more extended posture at the elbow $(\mathrm{ES}=4.09)$ and wrist $(\mathrm{ES}=3.71)$ at rest at the end of the intervention. At the wrist, participants improved their range of passive extension $(\mathrm{ES}=2.69)$ as well as active flexion and extension $(\mathrm{ES}=2.73)$. At the elbow, active ROM of elbow movement increased $(\mathrm{ES}=6.91)$.

Kang and colleagues ${ }^{50}$ assessed the effects of $2 \mathrm{~mA}$ anodal tDCS to the left dorsolateral prefrontal cortex on reaction time to an attention task. Nine individuals ( 8 males, 1 female) with chronic TBI participated and were randomized to receive active tDCS for 20 mins or sham stimulation after one week in a crossover fashion. Reaction time on a computerized timed task 
medRxiv preprint doi: https://doi.org/10.1101/2020.11.12.20214478; this version posted August 16, 2021. The copyright holder for this preprint (which was not certified by peer review) is the author/funder, who has granted medRxiv a license to display the preprint in perpetuity.

It is made available under a CC-BY-NC-ND 4.0 International license .

decreased after application of real tDCS vs sham stimulation at the end of the intervention $(\mathrm{ES}=-$ 0.89). However, this change was not maintained at the two retention assessments ( 3 hours and 24 hours after the end of stimulation).

Middleton et $\mathrm{al}^{51}$ examined the effects of bi-hemispheric stimulation followed by robotic training on five participants with ABIs (TBI; $n=1$, stroke: $n=3$, stroke + TBI: $n=1)$. All participants performed strengthening and functional activities for a total of 40 minutes. Each participant received $1.5 \mathrm{~mA}$ intensity concurrent stimulation for the first 15 minutes. Results for participants post-TBI ( 2 males) revealed improvements only in FMA scores $(\mathrm{ES}=0.47)$, which were retained $(\mathrm{ES}=0.42)$. Participants post-TBI also reached the targets faster at the end of the intervention $\left(\mathrm{ES}=0.37\right.$; assessed by the $\mathrm{KINARM}^{\odot}$ robotic device $)$ and continued to improve 6 months later $(\mathrm{ES}=0.7)$.

Insert_Table_4_here

\section{E. Arm Ability Training (AAT)}

We found 1 study (excellent quality; Table 4C) that assessed the effects of AAT on motor performance outcomes and hand function. In this study by Platz and colleagues, ${ }^{52} 60$ participants (36 males, 24 females) with ABI (TBI: $n=15$, stroke: $n=45$ ) were randomized into three groups: a control group, a group receiving AAT and a group receiving AAT + knowledge of results (KR) feedback ( $n=20$ each). Activity performance was assessed using the time to complete the TEMPA (Test Evaluant les Membres Superieurs des Personnes Agees). Kinematic assessment of an aiming movement on a stylus between two targets was also conducted. Provision of AAT resulted in faster performance on the TEMPA $(\mathrm{ES}=0.95)$, which was retained one year later 
medRxiv preprint doi: https://doi.org/10.1101/2020.11.12.20214478; this version posted August 16, 2021. The copyright holder for this preprint (which was not certified by peer review) is the author/funder, who has granted medRxiv a license to display the preprint in perpetuity.

It is made available under a CC-BY-NC-ND 4.0 International license .

(ES=0.75). Participants receiving AAT also had faster aiming movements (ES=0.67). Providing

KR feedback did not enhance task performance.

\section{F. Stem Cell Transplantation}

We found 1 study (fair quality; Table 5A) assessing the effects of stem cell transplantation on motor impairment. This study ${ }^{53}$ examined the effects of provision of injection of mesenchymal stem cells derived from the umbilical cord. Forty participants (32 males, 8 females) with moderate to severe TBI were randomized to receive the injections or to a control group ( $n=20 /$ group). The cells were injected into the sub-arachnoid space after lumbar puncture performed between the $3^{\text {rd }}$ and $4^{\text {th }}$ or $4^{\text {th }}$ and $5^{\text {th }}$ vertebrae. Motor impairment was assessed using the FMA at baseline and 6 months after the injection. The Funtional Independence Measure (FIM) helped quantify assistance in activity performance. The intervention group had significantly better improvement in FMA scores than the control group for both the UL $(\mathrm{ES}=1.38)$ and $\mathrm{LL}(\mathrm{ES}=0.88)$ as well as FIM scores $(\mathrm{ES}=1.17)$.

$$
\text { Insert_Table_5_here }
$$

\section{G. Feedback and Other Interventions}

We found three studies (fair quality; Table 5B) that assessed the effects of different interventions on UL motor impairment and activity levels in individuals post-TBI. Sietsema and colleagues $^{54}$ assessed the effects of playing a game within an occupational context compared to rote exercises on UL movement patterns. Twenty individuals (17 males, 3 females) with mild to moderate TBI participated in the study. Participants practiced 10 trials in both conditions. The total forward reaching distance from the hip to the wrist was measured using motion analysis. 
medRxiv preprint doi: https://doi.org/10.1101/2020.11.12.20214478; this version posted August 16, 2021. The copyright holder for this preprint (which was not certified by peer review) is the author/funder, who has granted medRxiv a license to display the preprint in perpetuity.

It is made available under a CC-BY-NC-ND 4.0 International license .

Game playing resulted in greater reaching distance $(13 \mathrm{~cm}$ more, $\mathrm{ES}=0.63)$ than rote arm reaching exercises.

Croce and colleagues ${ }^{55}$ evaluated the effectiveness of provision of knowledge of results (KR) feedback at different schedules in subjects with severe TBI $(\mathrm{n}=51 ; 42$ males, 9 females $)$. All participants practiced 60 trials ( 5 trials/block, 12 blocks) of an anticipation task. Participants received KR feedback on timing errors after each trial at different schedules - no KR $(n=12)$, $100 \% \mathrm{KR}(\mathrm{n}=14)$, summary KR $(\mathrm{n}=13)$ and average KR $(\mathrm{n}=12)$. They were then tested for immediate (after 10 minutes) and delayed (after one hour) retention. All the three KR groups were more accurate in the last block compared to the first block of trials (ES=0.96). At early retention testing, this effect was decreased in the $100 \%$ KR group. However, the summary KR $(\mathrm{ES}=1.21)$ and average $\mathrm{KR}(\mathrm{ES}=1.02)$ groups continued to improve accuracy. At the late retention testing, the effects were further reduced in the $100 \% \mathrm{KR}$ group $(\mathrm{ES}=0.37)$ and average KR group ( $\mathrm{ES}=0.77)$ but was retained only in the summary KR group at the same level $(\mathrm{ES}=1.21)$

Sterr and Freivogel ${ }^{56}$ examined the effects of shaping principles on UL activity performance in 13 individuals (9 males, 4 females) with ABIs (TBI: $n=11$, stroke: $n=2$ ). All participants were evaluated using the MAL, WMFT and Frenchay Arm Test. Compared to provision of Occupational Therapy, task-practice using shaping principles resulted in greater motor improvement on all outcomes (MAL; AoU: ES=2.23, QoM: ES=1.98), WMFT; ES=1.76 and the Frenchay Arm Test; ES=0.72).

\section{Discussion:}

We examined the effectiveness of different interventions to augment UL motor improvement in individuals post-TBI. Majority of the studies reported moderate to large effect 
medRxiv preprint doi: https://doi.org/10.1101/2020.11.12.20214478; this version posted August 16, 2021. The copyright holder for this preprint (which was not certified by peer review) is the author/funder, who has granted medRxiv a license to display the preprint in perpetuity.

It is made available under a CC-BY-NC-ND 4.0 International license .

sizes for intervention effectiveness. In terms of quality assessment, one study was excellent, five good and the rest were fair.

\section{Outcomes used to assess motor improvement}

A variety of outcomes were used to assess motor improvements at different levels of the International Classification of Functioning (ICF). ${ }^{57}$ At the motor impairment level, the FMA was the used most commonly. ${ }^{41,42,48,51,53}$ Goniometry $^{34,35,49}$ and torque controlled passive extension ${ }^{37}$ helped assess changes in wrist and elbow ranges of motion. In addition, kinematic motor performance outcomes including speed, reaching path straightness and accuracy helped quantify motor impairment. ${ }^{44-46}$ These kinematic measures were obtained using motion capture equipment, robotic manipulandum or using instrumented tablets. All of the above-mentioned measures have well established psychometric properties. ${ }^{58,59}$

Muscle tone was most commonly quantified using the Ashworth's scale or the MAS. ${ }^{34,35,38}$ Other measures used included the Modified Tardieu Scale ${ }^{37}$ or neurophysiological (H-Reflex) measures. ${ }^{39}$ The MAS has been recommended as a measure of choice in published guidelines ${ }^{58}$ However, both the MAS and Modified Tardieu Scale have poor inter-rater reliability in individuals post-TBI. ${ }^{60}$ Use of the MAS alone does not distinguish between the tonic and phasic components of spasticity. ${ }^{61}$ Changes noted in H-reflex based parameters do not automatically translate to better functional performance after rehabilitation. ${ }^{62}$ The utility of other neurophysiological measures (e.g. based on spatial threshold control of muscle activation ${ }^{61}$ alone or in conjunction with existing clinical measures to assess muscle tone remains to be estimated.

Similar to motor impairment, a variety of assessments were used to measure activity limitations. The WMFT was used most commonly ${ }^{40-42,56}$ across the different studies. Dexterity was measured by using the BBT, ${ }^{46,48,51}$ Purdue Pegboard Test, ${ }^{43}$ TEMPA $^{37,52}$ and Jebsen Taylor 
medRxiv preprint doi: https://doi.org/10.1101/2020.11.12.20214478; this version posted August 16, 2021. The copyright holder for this preprint (which was not certified by peer review) is the author/funder, who has granted medRxiv a license to display the preprint in perpetuity.

It is made available under a CC-BY-NC-ND 4.0 International license .

Hand Function test ${ }^{48}$ in different studies. Limitations in ADL performance were also quantified using the FIM, ${ }^{36,53}$ the CHART, ${ }^{36}$ Frenchay Arm Test $^{56}$ and the ARAT. ${ }^{40}$ In addition, studies also used the DASH ${ }^{47}$ MAL amount and quality scores, ${ }^{40-42,56}$ and the Stroke Impact Scale ${ }^{51}$ which report participant self-perceived levels of UL use. All the measures have excellent psychometric properties ${ }^{59}$ and the FIM and ARAT are part of the published guidelines. ${ }^{58}$ Inclusion of the DASH, MAL and Stroke Impact Scale across studies is encouraging, given the suggestion to use patient reported measures as outcomes in intervention studies. ${ }^{63}$

\section{Follow-up assessments}

It has been suggested that motor improvement after TBI is attributable in part to motor learning. ${ }^{12}$ Retention of improvements in performance noted at the end of the intervention denote motor learning. However, only $10^{36-39,41,44,51,52,55,56}$ studies included any form of retention testing. Amongst these studies, the timing of testing varied widely. Retention was tested at the following periods post-intervention: 10 minutes, ${ }^{55} 20$ minutes, ${ }^{39} 30$ minutes, ${ }^{44}$ one hour,${ }^{38}$ three hours, ${ }^{50} 24$ hours, ${ }^{37,50,55}$ four weeks, ${ }^{37,41,56}$ six weeks,${ }^{36}$ six months,${ }^{51}$ one year ${ }^{52}$ and two years postintervention. $^{41}$

Not all studies found that changes were retained. While hypertonia was reduced in the short-term ( $\leq 24 \mathrm{hrs})$ using casting ${ }^{37}$ and acupuncture, ${ }^{39}$ long-term retention $(>24$ hours $)$ was absent with oral tizanidine. ${ }^{36}$ Only short-term retention was assessed with $\mathrm{VR}^{44}$ and feedback provision. ${ }^{55}$ Use of shaping principles with ${ }^{41}$ and without ${ }^{56}$ constraint as well as Arm Motor Ability Training ${ }^{52}$ resulted in long-term retention. Both short ${ }^{50}$ and long-term ${ }^{51}$ retention were seen with the use of tDCS. It remains to be seen if use of VR technology and use of different interventions including acupuncture and Botulinum toxin A result in long-term retention in individuals post-TBI. 
medRxiv preprint doi: https://doi.org/10.1101/2020.11.12.20214478; this version posted August 16, 2021. The copyright holder for this preprint (which was not certified by peer review) is the author/funder, who has granted medRxiv a license to display the preprint in perpetuity.

It is made available under a CC-BY-NC-ND 4.0 International license.

\section{Presence of cognitive and mood impairments}

Dysfunction in different cognitive domains influences generalized motor improvement in individuals post-TBI. ${ }^{6}$ Only two ${ }^{42,50}$ of the selected studies, examined the association between UL motor improvement and cognitive impairment. Few other studies provided information on baseline levels of cognitive functioning, ${ }^{40,48,54,55}$ but did not examine the effects of baseline cognitive dysfunction with motor improvement. Only one study assessed the levels of baseline depressive symptomatology, ${ }^{48}$ which can predict motor improvement and satisfaction with life after discharge from rehabilitation in this population. ${ }^{64}$ The presence of cognitive impairments ${ }^{65}$ and depressive symptoms ${ }^{66}$ influence motor improvement after a stroke. Future studies will need to focus on the relationship between cognitive dysfunction, mood disorders and motor recovery in individuals post-TBI to better understand their association with motor improvement.

\section{Level of injury severity}

Out of the 23 included studies, only few studies reported initial injury severity levels. The Glasgow Coma Scale, ${ }^{34,35,37-39,53,55}$ duration of post-traumatic amnesia ${ }^{45}$ or Rancho Los Amigos original scale ${ }^{54}$ helped quantify initial injury severity levels. This information is an important prognostic indicator for changes in overall motor improvement and levels of activity performance assessed using the Barthel Index ${ }^{67}$ as well as a composite score of activities of daily living and social participation (assessed using the Glasgow Outcome Scale Extended measure). ${ }^{68}$

The other studies did not specify the injury severity levels, but some provided FMA scores. ${ }^{41,42,44,45,47,51}$ FMA scores $\geq 50 / 66$ and $\leq 49 / 66$ represent as mild and moderate-to-severe levels of post-stroke UL motor impairment. ${ }^{69}$ The FMA scores in the acute post-stroke stage can 
medRxiv preprint doi: https://doi.org/10.1101/2020.11.12.20214478; this version posted August 16, 2021. The copyright holder for this preprint (which was not certified by peer review) is the author/funder, who has granted medRxiv a license to display the preprint in perpetuity.

It is made available under a CC-BY-NC-ND 4.0 International license .

\section{Subramanian et al}

TBI upper limb motor improvement review

predict subsequent UL recovery potential. ${ }^{70}$ Whether UL FMA scores can be used to make similar predictions in individuals post-TBI remains to be estimated.

Sex and gender considerations:

As stated previously, a greater proportion of males (1.2-4.4) sustain TBIs compared to females. ${ }^{3,71}$ The greater proportion of males amongst the included participants across the different studies are indicative of the above findings. Only two studies had an almost equal distribution of sexes, ${ }^{46}$ or included more females. ${ }^{44}$ Despite consistent calls for considerations of sex and gender on functional outcomes, ${ }^{72,73}$ only one study ${ }^{47}$ assessed the effects of sex on outcomes. Future studies must strive to include more female participants and consider the effects of sex and gender on functional outcomes.

\section{Effect of chronicity}

Studies on interventions including acupuncture, CIMT, VR-based games, NMES, stemcells, game-playing, feedback, and forced-use therapy exclusively included participants with chronic injuries. While studies using Botulinum toxin A included acute, sub-acute and chronic participants, separate analyses were conducted by chronicity. ${ }^{34}$ Use of serial-casting ${ }^{37}$ included only participants in the sub-acute stage. Other studies including participants across all stages did not conduct-separate analyses based upon chronicity. ${ }^{38,50,52}$ Future studies must strive to include participants across all stages or conduct sub-analyses based on time since injury.

\section{Limitations:}

Heterogeneity amongst the interventions used prevented performance of an overarching statistical synthesis like a meta-analysis. Amongst the 23 studies included in this review, only 9 
medRxiv preprint doi: https://doi.org/10.1101/2020.11.12.20214478; this version posted August 16, 2021. The copyright holder for this preprint (which was not certified by peer review) is the author/funder, who has granted medRxiv a license to display the preprint in perpetuity.

It is made available under a CC-BY-NC-ND 4.0 International license .

studies were designed as RCTs. Although the wide variability in presenting symptoms and underlying injury severity present serious challenges in designing RCTs involving individuals post-TBI, ${ }^{74}$ encouraging efforts are underway. ${ }^{75}$ Only three studies included in this review had sample size calculations $\mathrm{s}^{37,45,52}$ and one study ${ }^{48}$ provided an estimate for numbers of participants needed for future trials. Nine of the 23 studies included participants with stroke and TBI. Thus, generalization of the findings is limited to a certain extent, except for two studies, ${ }^{47,51}$ which conducted separate analyses for individuals post-TBI. Future studies should include only individuals post-TBI or conduct separate sub-analyses for this population. Limits placed on age (adults), language (English only) and non-inclusion of terms like shoulder, elbow, wrist, hand, etc. may have led to exclusion of some studies.

\section{Conclusion}

Preliminary evidence suggests that different rehabilitation interventions may facilitate UL motor improvement in individuals post-TBI. This systematic review has identified several new questions in individuals post-TBI including whether provision of: i) Botulinum toxin A followed by intensive rehabilitation results in better long-term reduction of muscle tone; ii) CIMT results in better motor improvement compared to traditional therapy; iii) a combination of interventions such as VR-based gaming and tDCS is more beneficial than provision of one single intervention; and iv) provision of knowledge of performance feedback is useful and results in similar or better improvements than KR feedback. We hope that these questions will help guide and foster further research to evaluate the efficacy of the most suitable interventions to reduce impairment and improve activity performance post-TBI. 
medRxiv preprint doi: https://doi.org/10.1101/2020.11.12.20214478; this version posted August 16, 2021. The copyright holder for this preprint (which was not certified by peer review) is the author/funder, who has granted medRxiv a license to display the preprint in perpetuity.

It is made available under a CC-BY-NC-ND 4.0 International license .

\section{Acknowledgements}

The authors would like to acknowledge Dr. Kate Aultman for her support and encouragement in this project.

\section{Declaration of Conflicting Interests}

The authors declare no potential conflicts of interest with respect to the research, authorship, and/or publication of this article.

\section{Funding}

SKS was funded by a pilot grant awarded by the School of Health Profession, UT Health San Antonio.

\section{References}

1. James SL, Theadom A, Ellenbogen RG, et al. Global, regional, and national burden of traumatic brain injury and spinal cord injury, 1990-2016: a systematic analysis for the Global Burden of Disease Study 2016. Lancet Neurol. 2019;18:56-87.

2. Traumatic Brain Injury \& Concussion: Basic Information. [Internet]. Atlanta (GA) Center for Disease Control and Prevention https://www.cdc.gov/traumaticbraininjury/get_the_ facts.html

3. Taylor CA, Bell JM, Breiding MJ, Xu L. Traumatic brain injury-related emergency department visits, hospitalizations, and deaths-United States, 2007 and 2013. MMWR CDC Surveill Summ. 2017;66:1-16. 
medRxiv preprint doi: https://doi.org/10.1101/2020.11.12.20214478; this version posted August 16, 2021. The copyright holder for this preprint (which was not certified by peer review) is the author/funder, who has granted medRxiv a license to display the preprint in perpetuity.

It is made available under a CC-BY-NC-ND 4.0 International license .

4. Dixon KJ. Pathophysiology of traumatic train injury. Phys Med Rehabil Clin N Am. 2017;28:215-225.

5. Capizzi A, Woo J, Verduzco-Gutierrez M. Traumatic brain injury: An overview of epidemiology, pathophysiology, and medical management. Med Clin North Am. 2020; $104: 213-238$.

6. Allanson F, Pestell C, Gignac GE, Yeo YX, Weinborn M. Neuropsychological predictors of outcome following traumatic brain injury in adults: A meta-analysis. Neuropsychol Rev. 2017; 27:187-201.

7. Weber E, Spirou A, Chiaravalloti N, Lengenfelder J. Impact of frontal neurobehavioral symptoms on employment in individuals with TBI. Rehabil Psychol. 2018;63:383-391.

8. Meulenbroek P, Turkstra LS. Job stability in skilled work and communication ability after moderate-severe traumatic brain injury. Disabil Rehabil. 2016;38:452-61.

9. Oberholzer M, Muri RM. Neurorehabilitation of Traumatic Brain Injury (TBI): A Clinical Review. Med Sci (Basel). 2019;7(3), doi:10.3390/medsci7030047

10. Fulk GD, Nirider C. Physical rehabilitation. 7th ed. FA Davis; 2019.

11. Lamontagne ME, Bayley MT, Marshall S, et al. Assessment of users' needs and expectations toward clinical practice guidelines to support the rehabilitation of adults With moderate to severe Traumatic Brain Injury. J Head Trauma Rehabil. 2018;33:288295.

12. Breceda EY, Dromerick AW. Motor rehabilitation in stroke and traumatic brain injury: stimulating and intense. Curr Opin Neurol. 2013;26:595-601.

13. Glenn MB, Shih SL. Rehabilitation Following TBI. In: Tsao JW, ed. Traumatic Brain Injury: A Clinician's Guide to Diagnosis, Management, and Rehabilitation. Springer; 2020:293-327. 
medRxiv preprint doi: https://doi.org/10.1101/2020.11.12.20214478; this version posted August 16, 2021. The copyright holder for this preprint (which was not certified by peer review) is the author/funder, who has granted medRxiv a license to display the preprint in perpetuity.

It is made available under a CC-BY-NC-ND 4.0 International license .

14. Kleim JA, Jones TA. Principles of experience-dependent neural plasticity: implications for rehabilitation after brain damage. J Speech Lang Hear Res 2008;51:S225-S239.

15. Bayley M, Swaine B, Lamontagne ME, et al. INESSS-ONF Clinical Practice Guideline for the Rehabilitation of Adults with Moderate to Severe Traumatic Brain Injury. Ontario Neurotrauma Foundation. 2018; https://braininjuryguidelines.org/modtosevere Accessed July 25, 2021

16. Dobkin BH. Motor rehabilitation after stroke, traumatic brain, and spinal cord injury: common denominators within recent clinical trials. Curr Opin Neurol. 2009;22:563-569.

17. Vanderbeken I, Kerckhofs E. A systematic review of the effect of physical exercise on cognition in stroke and traumatic brain injury patients. NeuroRehabilitation. 2017;40:3348.

18. Hellweg S, Johannes S. Physiotherapy after traumatic brain injury: a systematic review of the literature. Brain Inj. 2008;22:365-373.

19. Jang SH. Review of motor recovery in patients with traumatic brain injury. NeuroRehabilitation. 2009;24:349-353.

20. McCrea PH, Eng JJ, Hodgson AJ. Biomechanics of reaching: clinical implications for individuals with acquired brain injury. Disabil Rehabil. 2002;24:534-541.

21. Andelic N, Sigurdardottir S, Tenovuo O. Rehabilitation after severe TBI. In: Sundstrom T, Grände P-O, Luoto T, Rosenlund C, Undén J, Wester KG, eds. Management of Severe Traumatic Brain Injury Evidence, Tricks, and Pitfalls. 2nd ed. Springer; 2020:547-556.

22. Perumparaichallai RK, Lewin RK, Klonoff PS. Community reintegration following holistic milieu-oriented neurorehabilitation up to 30 years post-discharge.

NeuroRehabilitation. 2020;46:243-253. 
medRxiv preprint doi: https://doi.org/10.1101/2020.11.12.20214478; this version posted August 16, 2021. The copyright holder for this preprint (which was not certified by peer review) is the author/funder, who has granted medRxiv a license to display the preprint in perpetuity.

It is made available under a CC-BY-NC-ND 4.0 International license.

23. Soeker MS, Van Rensburg V, Travill A. Individuals with traumatic brain injuries perceptions and experiences of returning to work in South Africa. Work. 2012;42:589600.

24. Eriksen MB, Frandsen TF. The impact of patient, intervention, comparison, outcome (PICO) as a search strategy tool on literature search quality: a systematic review. J Med Libr Assoc. 2018;106:420-431.

25. Subramanian SK, Fountain M, Hood A. Interventions to augment upper extremity motor improvement in individuals with a Traumatic Brain Injury: A systematic review [abstract]. Neurorehabil Neural Repair. 2018;32:1110-1111.

26. Husted JA, Cook RJ, Farewell VT, Gladman DD. Methods for assessing responsiveness: a critical review and recommendations. J Clin Epidemiol. 2000;53:459-468.

27. Cohen J. The effect size index: d. Statistical power analysis for the behavioral sciences. $1988 ; 2: 284-288$.

28. Morton S, Barton CJ, Rice S, Morrissey D. Risk factors and successful interventions for cricket-related low back pain: a systematic review. Br J Sports Med. 2014;48:685-691.

29. Downs SH, Black N. The feasibility of creating a checklist for the assessment of the methodological quality both of randomised and non-randomised studies of health care interventions. J Epidemiol Comm Health. 1998;52:377-384.

30. Hootman JM, Driban JB, Sitler MR, Harris KP, Cattano NM. Reliability and validity of three quality rating instruments for systematic reviews of observational studies. Res Synth Methods. 2011;2(2):110-118. doi:10.1002/jrsm.41

31. Aubut JA, Marshall S, Bayley M, Teasell RW. A comparison of the PEDro and Downs and Black quality assessment tools using the acquired brain injury intervention literature. NeuroRehabilitation. 2013;32:95-102. doi:10.3233/NRE-130826 
medRxiv preprint doi: https://doi.org/10.1101/2020.11.12.20214478; this version posted August 16, 2021. The copyright holder for this preprint (which was not certified by peer review) is the author/funder, who has granted medRxiv a license to display the preprint in perpetuity.

It is made available under a CC-BY-NC-ND 4.0 International license .

32. Subramanian SK, Caramba SM, Hernandez OL, Morgan QT, Cross MK, Hirschhauser CS. Is the Downs and Black scale a better tool to appraise the quality of the studies using virtual rehabilitation for post-stroke upper limb rehabilitation? In: Wright WG, Subramanian SK, Fluet GG, Agmon M, eds. Proceedings of the 2019 International Conference on Virtual Rehabilitation (ICVR); 2019 Jul 22-24. Tel Aviv (Israel): IEEE Publications. doi: 10.1109/ICVR46560.2019. 8994724

33. O’Connor SR, Tully MA, Ryan B, Bradley JM, Baxter GD, McDonough SM. Failure of a numerical quality assessment scale to identify potential risk of bias in a systematic review: a comparison study. BMC Res Notes. 2015;8(1):224. doi: 10.1186/s13104-0151181-1.

34. Yablon SA, Agana BT, Ivanhoe CB, Boake C. Botulinum toxin in severe upper extremity spasticity among patients with traumatic brain injury: an open-labeled trial. Neurology. 1996;47: 939-944.

35. Pavesi G, Brianti R, Medici D, Mammi P, Mazzucchi A, Mancia D. Botulinum toxin type A in the treatment of upper limb spasticity among patients with traumatic brain injury. $J$ Neurol, Neurosurg Psychiatr. 1998;64:419-420.

36. Meythaler JM, Guin-Renfroe S, Johnson A, Brunner RM. Prospective assessment of tizanidine for spasticity due to acquired brain injury. Arch Phys Med Rehabil. 2001;

\section{$82: 1155-1163$.}

37. Moseley AM, Hassett LM, Leung J, Clare JS, Herbert RD, Harvey LA. Serial casting versus positioning for the treatment of elbow contractures in adults with traumatic brain injury: a randomized controlled trial. Clin Rehabil. 2008;22:406-417. 
medRxiv preprint doi: https://doi.org/10.1101/2020.11.12.20214478; this version posted August 16, 2021. The copyright holder for this preprint (which was not certified by peer review) is the author/funder, who has granted medRxiv a license to display the preprint in perpetuity.

It is made available under a CC-BY-NC-ND 4.0 International license .

38. Thibaut A, Deltombe T, Wannez S, et al. Impact of soft splints on upper limb spasticity in chronic patients with disorders of consciousness: A randomized, single-blind, controlled trial. Brain Inj. 2015;29:830-836.

39. Matsumoto-Miyazaki J, Asano Y, Yonezawa S, et al. Acupuncture increases the excitability of the cortico-spinal system in patients with chronic disorders of consciousness following traumatic brain injury. J Altern Complement Med. 2016;22:887894.

40. Page S, Levine P. Forced use after TBI: promoting plasticity and function through practice. Brain Inj. 2003;17:675-84.

41. Shaw SE, Morris DM, Uswatte G, McKay S, Meythaler JM, Taub E. Constraint-induced movement therapy for recovery of upper-limb function following traumatic brain injury. J Rehabil Res Dev. 2005;42:769-778.

42. Morris DM, Shaw SE, Mark VW, Uswatte G, Barman J, Taub E. The influence of neuropsychological characteristics on the use of CI therapy with persons with traumatic brain injury. NeuroRehabilitation. 2006;21:131-137.

43. Cho YW, Jang SH, Lee ZI, Song JC, Lee HK, Lee HY. Effect and appropriate restriction period of constraint-induced movement therapy in hemiparetic patients with brain injury: a brief report. NeuroRehabilitation. 2005;20:71-74.

44. Ustinova KI, Leonard WA, Cassavaugh ND, Ingersoll CD. Development of a 3D immersive videogame to improve arm-postural coordination in patients with TBI. $J$ Neuroeng Rehabil. 2011;8:61. doi:10.1186/1743-0003-8-61

45. Ustinova KI, Perkins J, Leonard WA, Hausbeck CJ. Virtual reality game-based therapy for treatment of postural and co-ordination abnormalities secondary to TBI: a pilot study. Brain Inj. 2014;28:486-495. 
medRxiv preprint doi: https://doi.org/10.1101/2020.11.12.20214478; this version posted August 16, 2021. The copyright holder for this preprint (which was not certified by peer review) is the author/funder, who has granted medRxiv a license to display the preprint in perpetuity.

It is made available under a CC-BY-NC-ND 4.0 International license .

46. Mumford N, Duckworth J, Thomas PR, Shum D, Williams G, Wilson PH. Upper-limb virtual rehabilitation for traumatic brain injury: a preliminary within-group evaluation of the elements system. Brain Inj. 2012;26:166-176.

47. Syed UE, Kamal A. Video game-based and conventional therapies in patients of neurological deficits: an experimental study. Disabil Rehabil Assist Technol. 2021;16:332-339, published online November 05, 2019.

48. Buccellato KH, Nordstrom M, Murphy JM, et al. A randomized feasibility trial of a novel, integrative, and intensive virtual rehabilitation program for service members postacquired brain injury. Mil Med. 2020;185:e203-e211.

49. Alon G, Dar A, Katz-Behiri D, Weingarden H, Nathan R. Efficacy of a hybrid upper limb neuromuscular electrical stimulation system in lessening selected impairments and dysfunctions consequent to cerebral damage. J Neuro Rehab. 1998;12:73-79.

50. Kang EK, Kim DY, Paik NJ. Transcranial direct current stimulation of the left prefrontal cortex improves attention in patients with traumatic brain injury: a pilot study. J Rehabil Med. 2012;44:346-350.

51. Middleton A, Fritz SL, Liuzzo DM, Newman-Norlund R, Herter TM. Using clinical and robotic assessment tools to examine the feasibility of pairing tDCS with upper extremity physical therapy in patients with stroke and TBI: a consideration-of-concept pilot study. NeuroRehabilitation. 2014;35:741-754. doi:10.3233/NRE-141178

52. Platz T, Winter T, Müller N, Pinkowski C, Eickhof C, Mauritz K-H. Arm ability training for stroke and traumatic brain injury patients with mild arm paresis: a single-blind, randomized, controlled trial. Arch Phys Med Rehabil. 2001;82:961-968. 
medRxiv preprint doi: https://doi.org/10.1101/2020.11.12.20214478; this version posted August 16, 2021. The copyright holder for this preprint (which was not certified by peer review) is the author/funder, who has granted medRxiv a license to display the preprint in perpetuity.

It is made available under a CC-BY-NC-ND 4.0 International license.

53. Wang S, Cheng H, Dai G, et al. Umbilical cord mesenchymal stem cell transplantation significantly improves neurological function in patients with sequelae of traumatic brain injury. Brain Res. 2013;1532:76-84.

54. Sietsema JM, Nelson DL, Mulder RM, Mervau-Scheidel D, White BE. The use of a game to promote arm reach in persons with traumatic brain injury. Am J Occup Ther. 1993;47:19-24.

55. Croce R, Horvat M, Roswal G. Augmented feedback for enhanced skill acquisition in individuals with traumatic brain injury. Percept Mot Skills. 1996;82:507-514.

56. Sterr A, Freivogel S. Motor-improvement following intensive training in low-functioning chronic hemiparesis. Neurology. 2003;61:842-844.

57. Stucki G, Cieza A, Ewert T, Kostanjsek N, Chatterji S, Ustun TB. Application of the International Classification of Functioning, Disability and Health (ICF) in clinical practice. Disabil Rehabil. 2002;24:281-282.

58. McCulloch KL, De Joya AL, Hays K, et al. Outcome measures for persons with moderate to severe traumatic brain injury: recommendations from the American Physical Therapy Association Academy of Neurologic Physical Therapy TBI EDGE Task Force. J Neurol Phys Ther. 2016;40:269-280.

59. Rehabilitation Measures database [Internet]. www.sralab.org/rehabilitation-measures Accessed July 25, 2021

60. Mehrholz J, Wagner K, Meissner D, et al. Reliability of the Modified Tardieu Scale and the Modified Ashworth Scale in adult patients with severe brain injury: a comparison study. Clin Rehabil. 2005;19:751-759.

61. Subramanian SK, Feldman AG, Levin MF. Spasticity may obscure motor learning ability after stroke. J Neurophysiol. 2018;119:5-20. 
medRxiv preprint doi: https://doi.org/10.1101/2020.11.12.20214478; this version posted August 16, 2021. The copyright holder for this preprint (which was not certified by peer review) is the author/funder, who has granted medRxiv a license to display the preprint in perpetuity.

It is made available under a CC-BY-NC-ND 4.0 International license .

62. Elovic EP, Simone LK, Zafonte R. Outcome assessment for spasticity management in the patient with traumatic brain injury: the state of the art. J Head Trauma Rehabil. 2004;19:155-177.

63. Winstein $\mathrm{C}$. Thoughts about the negative results of clinical trials in rehabilitation medicine. Kinesiol Rev (Champaign). 2018;7:58-63.

64. Proctor CJ, Best LA. Social and psychological influences on satisfaction with life after brain injury. Disabil Health J. 2019;12:387-393.

65. Subramanian SK, Chilingaryan G, Sveistrup H, Levin MF. Influence of training environment and cognitive deficits on use of feedback for motor learning in chronic stroke. In: Deutsch J, Wright WG, Weiss PT, eds. Proceedings of the 2015 International Conference on Virtual Rehabilitation (ICVR); 2015 Jun 9-12. Valencia, Spain: IEEE Publications. doi: 10.1109/ICVR. 2015.7358582

66. Subramanian SK, Chilingaryan G, Sveistrup H, Levin MF. Depressive symptoms influence use of feedback for motor learning and recovery in chronic stroke. Restor Neurol Neurosci. 2015;33:727-740.

67. Kim DY, Pyun S-B. Prediction of functional outcome and discharge destination in patients with traumatic brain injury after post-acute rehabilitation. Int J Rehabil Res. 2019; 42: 256-262.

68. Kodliwadmath HB, Koppad SN, Desai M, Badiger SP. Correlation of Glasgow outcome score to Glasgow coma score assessed at admission. Int Surg J. 2016;3:1959-1963.

69. Subramanian SK, Yamanaka J, Chilingaryan G, Levin MF. Validity of movement pattern kinematics as measures of arm motor impairment poststroke. Stroke. 2010;41:2303-2308.

70. Stinear CM, Byblow WD, Ackerley SJ, Smith MC, Borges VM, Barber PA. Proportional motor recovery after stroke: Implications for trial design. Stroke. 2017;48:795-798. 
medRxiv preprint doi: https://doi.org/10.1101/2020.11.12.20214478; this version posted August 16, 2021. The copyright holder for this preprint (which was not certified by peer review) is the author/funder, who has granted medRxiv a license to display the preprint in perpetuity. It is made available under a CC-BY-NC-ND 4.0 International license .

\section{Subramanian et al}

TBI upper limb motor improvement review

71. Critchley G, Memon A. Epidemiology of head injury. In: Peter C. Whitfield JW, Elfyn Thomas, Fiona Summers, Maggie Whyte, Peter J. Hutchinson, ed. Traumatic Brain Injury: A Multidisciplinary Approach. Cambridge University Press; 2020:1-10.

72. Mollayeva T, Mollayeva S, Colantonio A. Traumatic brain injury: sex, gender and intersecting vulnerabilities. Nat. Rev. Neurol. 2018;14:711-722.

73. Hanafy S, Amodio V, Haag HL, et al. Is it prime time for sex and gender considerations in traumatic brain injury? Perspectives of rehabilitation care professionals. Disabil Rehabil. 2020:1-9.

74. Turner-Stokes L, Pick A, Nair A, Disler PB, Wade DT. Multi-disciplinary rehabilitation for acquired brain injury in adults of working age. Cochrane Database Syst Rev. Dec 22 2015;(12):CD004170. doi:10.1002/14651858.CD004170.pub3

75. Morris DM, Taub E, Mark VW, et al. Protocol for a randomized controlled trial of CI therapy for rehabilitation of upper extremity motor deficit: The bringing rehabilitation to American veterans everywhere project. J Head Trauma Rehabil. 2019;34:268-279. 
medRxiv preprint doi: https://doi.org/10.1101/2020.11.12.20214478; this version posted August 16, 2021. The copyright holder for this preprint (which was not certified by peer review) is the author/funder, who has granted medRxiv a license to display the preprint in perpetuity.

It is made available under a CC-BY-NC-ND 4.0 International license.

Subramanian et al

TBI upper limb motor improvement review

Figure Legend

Figure 1: Preferred Reporting Items for Systematic Reviews and Meta-Analyses (PRISMA) flow 
medRxiv preprint doi: https://doi.org/10.1101/2020.11.12.20214478; this version posted August 16, 2021. The copyright holder for this preprint (which was not certified by peer review) is the author/funder, who has granted medRxiv a license to display the preprint in perpetuity.

It is made available under a CC-BY-NC-ND 4.0 International license.

Abbreviations:

TBI : Traumatic Brain Injury

UL: Upper Limb

LL: Lower Limb

PICO: Patient, Intervention, Comparison, Outcome

MKF: Melinda K Fountain (2 $2^{\text {nd }}$ author)

AFH: Ashley F Hood ( $3^{\text {rd }}$ author $)$

SKS: Sandeep K Subramanian ( $1^{\text {st }}$ author)

ES: Effect Size

MAS: Modified Ashworth's Scale

ABI: Acquired Brain Injury

CIMT: Constraint Induced Movement Therapy

MAL: Motor Activity Log

FMA: Fugl-Meyer Assessment

WMFT: Wolf Motor Function Test

BBT: Box and Blocks Test

BBT: Box and Block Test

DASH: Disabilities of the Arm, Shoulder and Hand

BBS: Berg Balance Scale

NMES: NeuroMuscular Electrical Stimulation

FIM: functional Independence Measure

ICF: International Classification of Functioning, Disability and Health

CHART: Craig Handicap Assessment and Reporting Technique

ARAT: Action Research Arm Test 
Table 1 Interventions to reduce muscle tone in the upper limbs

\begin{tabular}{|c|c|c|c|c|c|c|}
\hline $\begin{array}{l}\text { Study; } \\
\text { Sample } \\
\text { size }(n) \\
\text { and } \\
\text { Down's } \\
\text { and Black } \\
\text { score }\end{array}$ & $\begin{array}{c}\text { Chronicity and } \\
\text { severity of injury }\end{array}$ & Intervention & $\begin{array}{l}\text { Rehabilitation } \\
\text { provided/Dose }\end{array}$ & Outcomes & $\begin{array}{l}\text { Timing of } \\
\text { assessment }\end{array}$ & Results \\
\hline $\begin{array}{l}\text { Yablon et } \\
\text { al 1996; } \\
\mathrm{n}=21 \\
\text { DBS } 17 \\
\text { (fair) }\end{array}$ & $\begin{array}{l}\text { - } 9 \text { acute and } 12 \\
\text { chronic. } \\
\text { - } \text { Majority had } \\
\text { severe injuries } \\
(\text { GCS } \leq 8)\end{array}$ & $\begin{array}{l}20-40 \text { units of } \\
\text { Botulinum Toxin } \\
\text { A injected under } \\
\text { EMG guidance. }\end{array}$ & $\begin{array}{l}\text { ROM therapy, } \\
\text { casting and/or } \\
\text { modalities provided } \\
\text { as required. }\end{array}$ & $\begin{array}{l}\quad \text { Wrist: } \\
\text { Modified } \\
\text { Ashworth's scale } \\
\text { for flexors and } \\
\text { passive ROM } \\
\text { using goniometry. }\end{array}$ & $\begin{array}{l}\text { Baseline and } \\
\text { 2-4 weeks } \\
\text { after injections }\end{array}$ & $\begin{array}{l}\text { Acute TBI: } \\
\text { - Decrease in tone measured } \\
\text { by Modified Ashworth Scale; } \\
\text { ES =-2.83 } \\
\text { - All participants had a lower } \\
\text { MAS score (1-2 points), } \\
\text { which is MCID } \\
\text { - Improvement in wrist } \\
\text { extension ROM; ES = 1.52. } \\
\qquad \text { Chronic TBI: } \\
\text { - Decrease in tone measured } \\
\text { by Modified Ashworth } \\
\text { Scale; ES = -1.63 } \\
\text { - } 11 \text { out of 12 participants had } \\
\text { a lower MAS score (1-2 } \\
\text { points), which is MCID } \\
\text { - Improvement in wrist } \\
\text { extension ROM; ES = 1.74 }\end{array}$ \\
\hline $\begin{array}{l}\text { Pavesi et } \\
\text { al. } 1998 ; \\
\mathrm{n}=6 \\
\text { DBS } 14 \\
\text { (fair) }\end{array}$ & $\begin{array}{l}\text { - Spasticity } \\
\text { present for 4-6 } \\
\text { months post- } \\
\text { injury }\end{array}$ & $\begin{array}{l}20-40 \text { units of } \\
\text { Botox; injected } \\
\text { under EMG } \\
\text { guidance. }\end{array}$ & $\begin{array}{l}\text { - After injections, } \\
\text { casting was provided. }\end{array}$ & $\begin{array}{l}\qquad \text { Wrist: } \\
\text { Modified } \\
\text { Ashworth's scale } \\
\text { for flexors and } \\
\text { passive ROM } \\
\text { using goniometry. }\end{array}$ & $\begin{array}{l}\text { Baseline and } 4 \\
\text { weeks after } \\
\text { injection }\end{array}$ & $\begin{array}{l}\text { - Decrease in tone measured by } \\
\text { Modified Ashworth Scale; ES } \\
=-2.38 \\
\text { - All participants had a lower } \\
\text { MAS score (1-2 points), } \\
\text { which is MCID }\end{array}$ \\
\hline
\end{tabular}




\begin{tabular}{|c|c|c|c|c|c|c|}
\hline & $\begin{array}{l}\text { Severe } \\
\text { injuries (GCS } \\
\leq 8)\end{array}$ & & & & & $\begin{array}{l}\text { - Improvement in wrist } \\
\text { extension ROM; ES = } \\
2.11\end{array}$ \\
\hline $\begin{array}{l}\text { Meythaler } \\
\text { et al 2001; } \\
\mathrm{n}=17(8 \\
\text { TBI) } \\
\text { DBS } 22 \\
\text { (good) }\end{array}$ & $\begin{array}{l}\text { - Spasticity } \\
\text { present for } \\
\text { atleast } 6 \text { mos. } \\
\text { before study } \\
\text { participation } \\
\text { - Initial injury } \\
\text { severity level } \\
\text { information } \\
\text { missing }\end{array}$ & $\begin{array}{l}\text { Oral Tizanidine } \\
\text { for a maximum of } \\
36 \mathrm{mg} / \mathrm{d} \text { or dose } \\
\text { tolerated for } 8 \\
\text { weeks followed } \\
\text { by placebo or vice } \\
\text { versa. }\end{array}$ & $\begin{array}{l}\text { No information } \\
\text { provided }\end{array}$ & $\begin{array}{l}\quad \text { Muscle tone: } \\
\text { Combined Original } \\
\text { Ashworth's scale } \\
\text { score for shoulder } \\
\text { abductors, elbow } \\
\text { muscles and wrist } \\
\text { extensors. } \\
\text { Activity } \\
\text { limitations: } \\
\text { Functional } \\
\text { Independence } \\
\text { Measure (FIM) } \\
\text { and Craig Hospital } \\
\text { Assessment and } \\
\text { Reporting } \\
\text { Technique. }\end{array}$ & $\begin{array}{l}\text { Baseline and } 4 \\
\text { weeks after } \\
\text { start of } \\
\text { medication. } \\
\text { Retention } \\
\text { assessment } \\
\text { only when } \\
\text { active drug } \\
\text { administered }\end{array}$ & $\begin{array}{l}\text { - Greater reduction in tone } \\
\text { with Tizanidine }(\mathrm{ES}=-0.36) \\
\text { compared to placebo }(\mathrm{ES}=- \\
0.23 ; \mathrm{p}<0.05) \\
\text { - Effect not retained. } \\
\text { - No improvements noted in } \\
\text { activity limitations. }\end{array}$ \\
\hline $\begin{array}{l}\text { Moseley et } \\
\text { al 2006; } \\
\mathrm{n}=26 \\
\text { DBS 22 } \\
\text { (good) }\end{array}$ & $\begin{array}{l}\text { Duration since } \\
\text { injury } \leq 6 \\
\text { months. } \\
\text { - } \\
\text { Severe injuries } \\
(\mathrm{GCS} \leq 5)\end{array}$ & $\begin{array}{l}\text { Serial casting } \\
(\mathrm{n}=14) \text { or } \\
\text { positioning } \\
(\mathrm{n}=12)\end{array}$ & \begin{tabular}{|l|} 
Serial casting group \\
- Elbows stretched in \\
an extended \\
position for 14 \\
days. \\
- Progressive \\
increase of stretch \\
range after first 7 \\
days. \\
Positioning group \\
- Passive stretch \\
applied for one \\
hour/day; 5-7 \\
days/week.
\end{tabular} & $\begin{array}{l}\quad \text { Primary: } \\
\text { Torque controlled } \\
\text { elbow extension. } \\
\quad \text { Secondary: } \\
\text { Tone assessed } \\
\text { using Modified } \\
\text { Tardieu Scale; } \\
\text { Function assessed } \\
\text { suing the Test } \\
\text { Évaluant la } \\
\text { Performance des } \\
\text { Membres } \\
\text { Supérieurs des } \\
\text { Personnes Âgées } \\
\text { (TEMPA). }\end{array}$ & $\begin{array}{l}\text { Baseline, } \\
\text { immediately } \\
\text { after cast } \\
\text { removal, and } \\
\text { at one month } \\
\text { retention. } \\
\text { An additional } \\
\text { assessment } \\
\text { conducted one } \\
\text { day after cast } \\
\text { removal for } \\
\text { the primary } \\
\text { outcome. }\end{array}$ & $\begin{array}{l}\quad \text { Primary Outcome } \\
\text { - Improved elbow extension } \\
\text { range by } 22^{\circ} \text { after serial } \\
\text { casting for } 2 \text { weeks; ES = } \\
1.31 \\
\text { - One day after cast removal, } \\
\text { gain in elbow range } \\
\text { decreased to } 15 \text { degrees; ES } \\
=1.17 \\
\text { - Gain of } 11^{\circ} \text { elbow extension } \\
\text { range maintained } 1 \text { day after } \\
\text { removal of stretch; ES = } \\
0.29 \\
\text { - Change was not maintained } \\
\text { at retention }\end{array}$ \\
\hline
\end{tabular}




\begin{tabular}{|c|c|c|c|c|c|c|}
\hline & & & 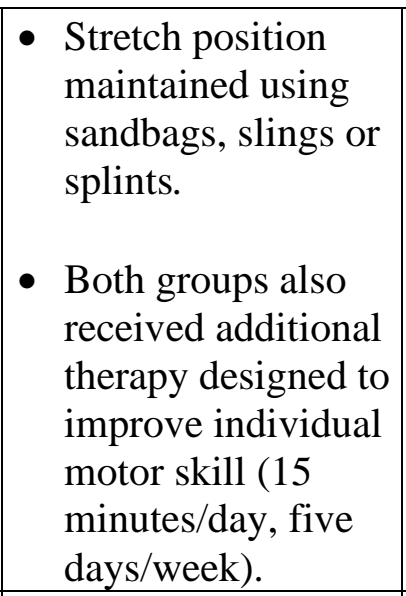 & & & $\begin{array}{l}\quad \text { Secondary Outcomes } \\
\text { - Tone reduced immediately } \\
\text { after serial casting compared } \\
\text { to positioning; ES = -1.19. } \\
\text { - Reduction in tone not } \\
\text { maintained at retention. } \\
\text { - Both groups improved on } \\
\text { TEMPA; no between group } \\
\text { differences seen. }\end{array}$ \\
\hline $\begin{array}{l}\text { Thibaut et } \\
\text { al 2015; } \\
\text { N =17 (7 } \\
\text { TBI) } \\
\text { DBS 20 } \\
\text { (good) }\end{array}$ & $\begin{array}{l}\text { - Duration since } \\
\text { injury } \geq 3 \\
\text { months. } \\
\text { - Severe } \\
\text { injuries }-6 \\
\text { participants } \\
\text { minimally } \\
\text { conscious and } \\
11 \text { in a } \\
\text { vegetative/ } \\
\text { unresponsive } \\
\text { wakeful state. }\end{array}$ & $\begin{array}{l}\text { Participants } \\
\text { received three } \\
\text { different one- } \\
\text { hour long } \\
\text { interventions in a } \\
\text { randomized } \\
\text { crossover fashion. }\end{array}$ & $\begin{array}{l}\text { The interventions } \\
\text { consisted of } \\
\text { a) stretching ( } 30 \\
\text { mins) and splint ( } 30 \\
\text { mins); } \\
\text { b) splint ( } 30 \text { mins) } \\
\text { and no treatment ( } 30 \\
\text { mins); } \\
\text { c) manual stretching } \\
\text { (30 mins) and no } \\
\text { treatment (30 mins). }\end{array}$ & $\begin{array}{l}\text { Modified Ashworth } \\
\text { Scale for finger } \\
\text { flexors and } \\
\text { passively measured } \\
\text { distance from thumb } \\
\text { to fingers. }\end{array}$ & $\begin{array}{l}\text { Baseline, } \\
\text { immediately } \\
\text { after treatment } \\
\text { and } 60 \\
\text { minutes after } \\
\text { treatment } \\
\text { (retention). }\end{array}$ & $\begin{array}{l}\text { Stretching and splinting: } \\
\text { Tone: } \\
\text { - Immediate decrease in } \\
\text { Modified Ashworth Scale } \\
\text { score after intervention; ES } \\
=-1.08 \\
\text { - Overall change in MAS } \\
\text { score by } 1 \text { point, which is } \\
\text { MCID. } \\
\text { - Reduction maintained at } \\
\text { retention; ES =-0.54 } \\
\text { Hand opening distance: } \\
\text { - Increased hand opening at } \\
\text { after intervention; ES = 0.55 } \\
\text { - Change not maintained at } \\
\text { retention. } \\
\text { Splinting only } \\
\text { - Immediate docrease in } \\
\text { Modified Ashworth Scale } \\
\text { score after intervention; ES } \\
=-0.68\end{array}$ \\
\hline
\end{tabular}




\begin{tabular}{|c|c|c|c|c|c|c|}
\hline & & & & & & $\begin{array}{l}\text { - Overall change in MAS } \\
\text { score by } 1 \text { point, which is } \\
\text { MCID. } \\
\text { - Reduction maintained at } \\
\text { retention; ES = - } 0.33 \\
\text { Hand opening distance: } \\
\text { - Increased hand opening at } \\
\text { POST compared to PRE; ES } \\
=0.75 \\
\text { - Change not maintained at } \\
\text { RET } \\
\text { Stretching only } \\
\text { - No significant changes seen } \\
\text { at POST or RET. }\end{array}$ \\
\hline $\begin{array}{l}\text { Matsumoto } \\
\text { - Miyazaki } \\
\text { et al. 2016; } \\
\mathrm{N}=11 \\
\text { DBS 20 } \\
\text { (good) }\end{array}$ & 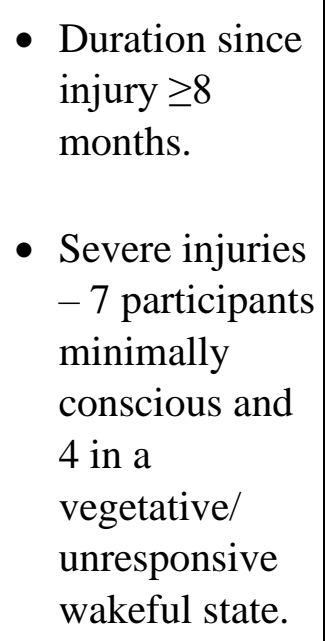 & $\begin{array}{l}\text { Acupuncture or } \\
\text { sham stimulation } \\
\text { provided. one } \\
\text { week apart in a } \\
\text { crossover } \\
\text { randomized } \\
\text { manner. }\end{array}$ & $\begin{array}{l}\text { Stimulation provided } \\
\text { on the face, dorsum } \\
\text { of the hand near the } \\
\text { second metacarpal } \\
\text { and anterior aspect of } \\
\text { leg near the tibialis } \\
\text { anterior muscle. } \\
\text { Stimulation } \\
\text { provided. for a total } \\
\text { of } 10 \text { minutes. }\end{array}$ & $\begin{array}{l}\text { Abductor Pollicis } \\
\text { Brevis F/M ratio. } \\
16 \mathrm{~F} \text { waves } \\
\text { recorded for the } \\
\text { Abductor Pollicis } \\
\text { Brevis muscle with } \\
\text { stimulation } \\
\text { provided at the } \\
\text { median nerve. }\end{array}$ & $\begin{array}{l}\text { Baseline, } \\
\text { immediately } \\
\text { after removal } \\
\text { of the needle } \\
\text { (10 minutes) } \\
\text { and at } 20 \\
\text { minutes }\end{array}$ & $\begin{array}{l}\quad \text { Acupuncture } \\
\text { - Decrease in F/M ratio after } \\
\text { immediately after } \\
\text { intervention; ES }=-0.73 \\
\text { - Change maintained at } \\
\text { retention; ES }=-0.70 . \\
\text { Sham stimulation } \\
\text { - No change in F/M ratio seen } \\
\text { post- stimulation or at } \\
\text { retention. }\end{array}$ \\
\hline
\end{tabular}

DBS: Downs and Black Checklist Score; TBI: Traumatic Brain Injury; GCS: Glasgow Coma Scale; EMG: Electromyography; ROM: Range of Motion; ABI: Acquired Brain Injury; ES: Effect Size; MCID : Minimal Clinically Important Difference 
Table 2. Use of Constraint Induced Movement Therapy (CIMT)

\begin{tabular}{|c|c|c|c|c|c|c|}
\hline $\begin{array}{l}\text { Study; } \\
\text { Sample } \\
\text { size (n) } \\
\text { and } \\
\text { Down's } \\
\text { and Black } \\
\text { score }\end{array}$ & $\begin{array}{l}\text { Chronicity and } \\
\text { severity of injury }\end{array}$ & Intervention & $\begin{array}{l}\text { Rehabilitation } \\
\text { provided/Dose }\end{array}$ & Outcomes & $\begin{array}{l}\text { Timing of } \\
\text { assessment }\end{array}$ & Results \\
\hline $\begin{array}{l}\text { Page and } \\
\text { Levine } \\
2003 ; \\
\mathrm{n}=3 \\
\text { DBS } 15 \\
\text { (fair) }\end{array}$ & $\begin{array}{l}\text { - All } \\
\text { participants } \\
\text { had chronic } \\
\text { injuries } \\
\text { - Initial injury } \\
\text { severity level } \\
\text { information } \\
\text { missing }\end{array}$ & $\begin{array}{l}\text { Modified CIMT. } \\
\text { Mitt worn on the } \\
\text { less-affected side }\end{array}$ & $\begin{array}{l}\text { All individuals wore } \\
\text { the mitt } 5 \text { days/week, } \\
\text { for } 5 \text { hours/day for } \\
10 \text { weeks. } \\
\text { They also received } \\
\text { three } 30 \text { mins long } \\
\text { sessions/week of } \\
\text { both PT and OT for } \\
10 \text { wks. }\end{array}$ & $\begin{array}{l}\text { - Motor Activity } \\
\text { Log Quality of } \\
\text { Movement } \\
\text { (MAL-QoM) and } \\
\text { Amount of Use } \\
\text { (MAL-AoU) } \\
\text { scales, } \\
\text { - Wolf Motor } \\
\text { Function Test - } \\
\text { Functional } \\
\text { Assessment Scale } \\
\text { (WMFT-FAS) and } \\
\text { - Action Research } \\
\text { Arm Test } \\
\text { (ARAT) }\end{array}$ & $\begin{array}{l}\text { - Baseline and } \\
\text { after } \\
\text { intervention } \\
\text { completion. }\end{array}$ & $\begin{array}{l}\text { - Improvements in MAL } \\
\text { QoM and AoU scales above } \\
\text { MCID levels. } \\
\text { - Improved WMFT - FAS } \\
(\mathrm{ES}=3.0) \text { and ARAT scores } \\
(\mathrm{ES}=1.78) \text { after } \\
\text { intervention completion. }\end{array}$ \\
\hline $\begin{array}{l}\text { Shaw et al } \\
2005 ; \\
\mathrm{n}=22 \\
\text { DBS } 18 \\
\text { (fair) }\end{array}$ & $\begin{array}{l}\text { - All } \\
\text { participants } \\
\text { had chronic } \\
\text { injuries } \\
\text { - Initial injury } \\
\text { severity level } \\
\text { information } \\
\text { missing }\end{array}$ & $\begin{array}{l}\text { Traditional } \\
\text { CIMT } \\
\text { The mitt was } \\
\text { worn } 90 \% \text { of } \\
\text { waking hours on } \\
\text { the less-affected } \\
\text { side. }\end{array}$ & $\begin{array}{l}\text { All individuals } \\
\text { practiced UL } \\
\text { activities for } 6 \mathrm{hrs} / \\
\text { day, } 5 \text { days/wk for } 2 \\
\text { wks. } \\
\text { Participants were } \\
\text { encouraged to } \\
\text { perform better and } \\
\text { explicit verbal } \\
\text { feedback on small } \\
\text { improvements was } \\
\text { provided. }\end{array}$ & $\begin{array}{l}\text { FMA, WMFT-FAS, } \\
\text { and MAL-QoM } \\
\text { scale. }\end{array}$ & $\begin{array}{l}\text { - All } \\
\text { assessments } \\
\text { completed at } \\
\text { baseline and } \\
\text { after } \\
\text { intervention } \\
\text { completion. } \\
\text { Only MAL- } \\
\text { QoM } \\
\text { additionally } \\
\text { assessed at } \\
\text { retention (one } \\
\text { mo. and } 2 \text { yrs). }\end{array}$ & $\begin{array}{l}\quad \underline{F M A \text { scores }} \\
\text { - Improved }(\mathrm{ES}=1.4) \text { scores } \\
\text { after intervention completion. } \\
\text { - Greater change seen in those } \\
\text { with mild-to-moderate }(\mathrm{ES} \\
=1.4) \text { and severe }(\mathrm{ES}=1.6) \\
\text { impairment compared to } \\
\text { moderate impairment }(\mathrm{ES}= \\
\text { 1.0). }\end{array}$ \\
\hline
\end{tabular}




\begin{tabular}{|c|c|c|c|c|c|c|}
\hline & & & & & & 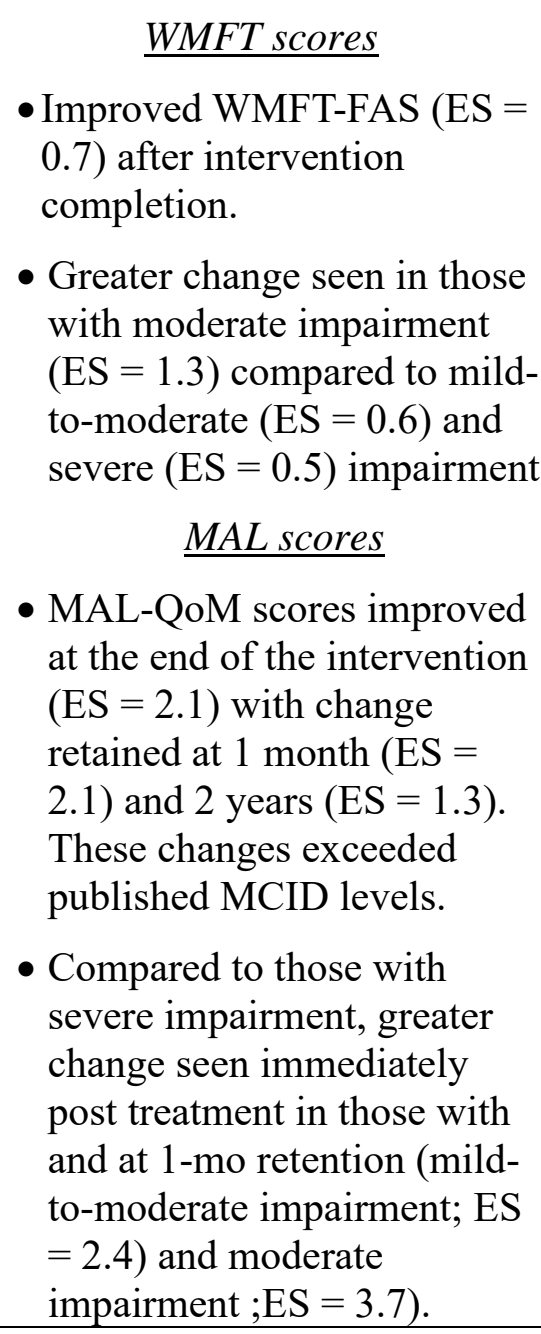 \\
\hline $\begin{array}{l}\text { Morris et } \\
\text { al. } 2006 \\
\mathrm{n}=29 \\
\text { DBS } 17 \\
\text { (fair) }\end{array}$ & $\begin{array}{ll}\text { - All } \\
\text { participants } \\
\text { had chronic } \\
\text { injuries } \\
\text { - Initial injury } \\
\text { severity level } \\
\text { information } \\
\text { missing }\end{array}$ & $\begin{array}{l}\text { Traditional } \\
\text { CIMT } \\
\text { The mitt was } \\
\text { worn } 90 \% \text { of } \\
\text { waking hours on } \\
\text { the less-affected } \\
\text { side. }\end{array}$ & $\begin{array}{l}\text { All individuals were } \\
\text { involved in } \\
\text { performance of UL } \\
\text { activities for } 6 \\
\text { hours/day, } 5 \\
\text { days/week for } 2 \\
\text { weeks }\end{array}$ & $\begin{array}{l}\text { - FMA, WMFT- } \\
\text { FAS, WMFT time } \\
\text { to complete } \\
\text { activities and } \\
\text { MAL QoM and } \\
\text { AoU scales. } \\
\text { - Visual attention, } \\
\text { task-switching } \\
\text { and global }\end{array}$ & $\begin{array}{l}\text { - Baseline and } \\
\text { after } \\
\text { intervention } \\
\text { completion. } \\
\text { - Cognitive } \\
\text { factors were } \\
\text { assessed as } \\
\text { part of } \\
\text { inclusion } \\
\text { criteria }\end{array}$ & $\begin{array}{l}\quad \text { FMA scores } \\
\text { - The intervention led to } \\
\text { improvements in FMA } \\
\text { scores (ES = 1.5) } \\
\quad \text { WMFT scores } \\
\text { - The intervention led to } \\
\text { improvements in WMFT } \\
\text { FAS scores (ES = 0.4) and }\end{array}$ \\
\hline
\end{tabular}




\begin{tabular}{|c|c|c|c|c|c|c|}
\hline & & & & $\begin{array}{l}\text { cognition were } \\
\text { also assessed }\end{array}$ & & $\begin{array}{l}\text { time to complete activities } \\
\text { (ES =0.2). } \\
\text { - Individuals were } 22.6 \% \\
\text { times faster in completing } \\
\text { activities, which is at MCID } \\
\text { levels. } \\
\qquad \text { MAL scores } \\
\text { - The intervention led to } \\
\text { improvements in and MAL } \\
\text { QoM (ES }=2.1 \text { ) and AoU } \\
\text { (ES = 1.7) scores. } \\
\text { - These changes exceeded } \\
\text { published MCID levels. } \\
\text { - Increase in self -perceived } \\
\text { arm use correlated with } \\
\text { better global cognition, } \\
\text { visual attention and task- } \\
\text { switching. }\end{array}$ \\
\hline $\begin{array}{l}\text { Cho et al. } \\
2005 ; \\
\mathrm{n}=9(3 \\
\text { TBI) } \\
\text { DBS } 14 \\
\text { (fair) }\end{array}$ & $\begin{array}{ll}\text { - } & \text { Injury } \\
\text { sustained } \geq 12 \\
\text { weeks before } \\
\text { study } \\
\text { participation. } \\
\text { - Initial injury } \\
\text { severity level } \\
\text { information } \\
\text { missing }\end{array}$ & $\begin{array}{l}\text { Traditional } \\
\text { CIMT with } \\
\text { splints that } \\
\text { prevented } \\
\text { contact of thumb } \\
\text { and index finger } \\
\text { on the less- } \\
\text { affected side } \\
\text { The three } \\
\text { participants with } \\
\text { TBI for two, } \\
\text { three or five } \\
\text { weeks. }\end{array}$ & $\begin{array}{l}\text { The individuals } \\
\text { continued with } \\
\text { whatever therapy } \\
\text { was previously } \\
\text { prescribed. } \\
\text { Exact details of dose } \\
\text { in terms of time } \\
\text { spent or numbers of } \\
\text { repetitions missing. }\end{array}$ & $\begin{array}{l}\text { - Perdue Pegboard } \\
\text { Test }\end{array}$ & $\begin{array}{l}\text { - Weekly, } \\
\text { scores on the } \\
\text { Perdue } \\
\text { Pegboard test } \\
\text { recorded and } \\
\text { scoring } \\
\text { stopped when } \\
\text { no change } \\
\text { was seen for } \\
3 \text { consecutive } \\
\text { weeks }\end{array}$ & $\begin{array}{l}\text { - Wearing splint resulted in } \\
\text { improved performance on } \\
\text { the test }(\mathrm{ES}=1.31) \text {. }\end{array}$ \\
\hline
\end{tabular}

DBS: Downs and Black Checklist Score; TBI: Traumatic Brain Injury; ABI: Acquired Brain Injury; FMA: Fugl Meyer Assessment; WMFT-FAS: Wolf Motor Function Test - Functional Assessment Scale; MAL-QoM : Motor Activity Log Quality of Movement; MAL-AoU: Motor Activity Log Amount of Use; ES: Effect Size; MCID: Minimal Clinically Important Difference 
Table 3. Use of Virtual Reality gaming

\begin{tabular}{|c|c|c|c|c|c|c|}
\hline $\begin{array}{l}\text { Study; } \\
\text { Sample } \\
\text { Size }(n) \\
\text { Down's } \\
\text { and Black } \\
\text { score } \\
\end{array}$ & $\begin{array}{c}\text { Chronicity and } \\
\text { severity of injury }\end{array}$ & Intervention & $\begin{array}{l}\text { Rehabilitation } \\
\text { provided/Dose }\end{array}$ & Outcomes & $\begin{array}{l}\text { Timing of } \\
\text { assessment }\end{array}$ & Results \\
\hline $\begin{array}{l}\text { Ustinova et } \\
\text { al. } 2011 \text {; } \\
\mathrm{n}=13 \\
\text { DBS } 18 \\
\text { (fair) }\end{array}$ & $\begin{array}{l}\text { - All participants } \\
\text { had chronic } \\
\text { injuries } \\
\text { - Mild to } \\
\text { moderate motor } \\
\text { impairment. }\end{array}$ & $\begin{array}{l}\text { Single session } \\
\text { consisting of } \\
10 \text { trials of } \\
\text { games ( } 90 \mathrm{sec} \\
\text { each) to pop } \\
\text { balloons. }\end{array}$ & $\begin{array}{l}\text { Every trial consisted } \\
\text { of } 20-25 \text { reaching } \\
\text { movements for a } \\
\text { total of } 200-250 \\
\text { reaches. }\end{array}$ & $\begin{array}{l}\text { Trajectory } \\
\text { straightness and } \\
\text { movement time }\end{array}$ & $\begin{array}{l}\text { Data for } \\
\text { reaching to } \\
\text { balloons in } \\
\text { front of the } \\
\text { participants } \\
\text { compared } \\
\text { between } 1 \mathrm{st} \\
\text { trial, 10th } \\
\text { trial and } 30 \\
\text { minutes post- } \\
\text { practice } \\
\text { (retention). }\end{array}$ & $\begin{array}{l}\text { Trajectory Straightness } \\
\text { - Participants had straighter } \\
\text { movements after } 10 \text { trials } \\
\text { ES }=1.07 . \\
\text { - These changes were } \\
\text { retained; ES = } 1.0 \\
\qquad \text { Movement Time } \\
\text { - Participants took less time } \\
\text { to complete reaches after } 10 \\
\text { trials; ES }=0.5 \\
\text { - These changes were } \\
\text { retained; ES }=0.5 .\end{array}$ \\
\hline $\begin{array}{l}\text { Ustinova } \\
\text { et al. } 2014 \text {; } \\
\mathrm{n}=15 \\
\text { DBS } 18 \\
\text { (fair) }\end{array}$ & $\begin{array}{l}\text { - All participants } \\
\text { had chronic } \\
\text { injuries. } \\
\text { - Severity was } \\
\text { either mild }(\mathrm{n}=5 \text {, } \\
\text { PTA <30 mins), } \\
\text { moderate }(\mathrm{n}=8 \text {, } \\
30 \text { mins } \\
<\text { PTA }<24 \text { hrs }) \text { or } \\
\text { severe }(\mathrm{n}=3 \text {; } \\
\text { PTA }>24 \text { hrs })\end{array}$ & $\begin{array}{l}15 \text { sessions of } \\
\text { exergaming. }\end{array}$ & $\begin{array}{l}\text { Sessions involving re- } \\
\text { training whole body } \\
\text { co-ordination, } \\
\text { including arm co- } \\
\text { ordination, posture and } \\
\text { gait. } \\
\text { Games included } \\
\text { collecting coins, } \\
\text { reaching for flowers, } \\
\text { and popping bubbles. } \\
2-31 \mathrm{hr} \text { sessions every } \\
\text { week. }\end{array}$ & $\begin{array}{l}\text { Trajectory } \\
\text { straightness for the } \\
\text { upper limb and } \\
\text { dynamic stability } \\
\text { index calculated } \\
\text { from trunk } \\
\text { displacement data } \\
\text { in the frontal plane. } \\
\text { Kinematic data } \\
\text { were obtained } \\
\text { using the Kinect } \\
\text { Sensor. }\end{array}$ & $\begin{array}{l}\text { - Baseline, } \\
\text { intervention } \\
\text { completion } \\
\text { and one- } \\
\text { month after } \\
\text { end of } \\
\text { intervention. }\end{array}$ & $\begin{array}{l}\text { - All participants had } \\
\text { straighter reaching } \\
\text { movements }(\mathrm{ES}=0.92) \text {. } \\
\text { and better dynamic } \\
\text { balance }(\mathrm{ES}=1.31) \text { at } \\
\text { intervention completion. } \\
\text { - These changes were not } \\
\text { retained. }\end{array}$ \\
\hline
\end{tabular}




\begin{tabular}{|c|c|c|c|c|c|c|}
\hline $\begin{array}{l}\text { Mumford } \\
\text { et al. 2012; } \\
\mathrm{n}=9 \\
\text { DBS } 17 \\
\text { (fair) }\end{array}$ & $\begin{array}{l}\text { - All participants } \\
\text { had chronic } \\
\text { injuries } \\
\text { - Severe to very } \\
\text { severe injuries } \\
\text { (duration of } \\
\text { PTA from 26- } \\
270 \text { days). }\end{array}$ & $\begin{array}{l}12 \text { one-hour } \\
\text { sessions } \\
\text { involving } \\
\text { reaching } \\
\text { movements. }\end{array}$ & $\begin{array}{l}\text { Movements involved } \\
\text { and goal directed } \\
\text { point to point } \\
\text { reaching exploring } \\
\text { different parts of the } \\
\text { arm workspace. } \\
\text { Each session was } 40 \\
\text { minutes long and the } \\
\text { intervention duration } \\
\text { was four weeks. }\end{array}$ & $\begin{array}{l}\text { Reaching Accuracy } \\
\text { Box \& Block Test }\end{array}$ & $\begin{array}{l}\text { Twice at } \\
\text { baseline and } \\
\text { once after } \\
\text { intervention } \\
\text { completion. }\end{array}$ & $\begin{array}{l}\quad \text { Reaching Accuracy } \\
\text { - Improved reaching } \\
\text { accuracy for both left (ES: } \\
=0.63 \text { ) and right UL (ES = } \\
0.54) \text {. } \\
\text { Box and Block Test } \\
\text { - Greater numbers of blocks } \\
\text { transferred at intervention } \\
\text { completion using both left } \\
(\mathrm{ES}=0.42) \text { and right } \\
\text { hands (ES = 0.61). } \\
\text { - Change of } 6 \text { blocks in right } \\
\text { hand above measurement } \\
\text { error and represents true } \\
\text { change }\end{array}$ \\
\hline $\begin{array}{l}\text { Syed and } \\
\text { Kamal } \\
2019 ; \\
\mathrm{n}=34(9 \\
\text { TBI) } \\
\text { DBS } 16 \\
\text { (fair) }\end{array}$ & $\begin{array}{l}\text { Details on } \\
\text { chronicity and } \\
\text { initial injury } \\
\text { severity not } \\
\text { provided. }\end{array}$ & $\begin{array}{l}\text { Participants } \\
\text { allotted to one } \\
\text { of two groups, } \\
\text { performing } \\
\text { exercises in } \\
\text { virtual reality } \\
\text { ( } \mathrm{n}=17,6 \mathrm{TBI}) \\
\text { or conventional } \\
\text { rehabilitation } \\
\text { ( } \mathrm{n}=17,3 \mathrm{TBI}) \text {. }\end{array}$ & $\begin{array}{l}\text { Virtual reality } \\
\text { exergaming involved } \\
\text { moving within base of } \\
\text { support, stepping, sit- } \\
\text { to-stand, skipping, } \\
\text { jumping, and jogging. } \\
\text { Conventional } \\
\text { rehabilitation involved } \\
\text { walking, picking up } \\
\text { objects from the floor, } \\
\text { moving within base of } \\
\text { support, jumping, } \\
\text { skipping and jogging. } \\
\text { All participants } \\
\text { received two } 40 \text { mins } \\
\text { sessions/wk for } 6 \text { wks. }\end{array}$ & $\begin{array}{l}\text { Disabilities of Arm } \\
\text { Shoulder and Hand } \\
\text { (DASH) } \\
\text { questionnaire and } \\
\text { Berg's Balance scale } \\
\text { (BBS). }\end{array}$ & $\begin{array}{l}\text { - Baseline and } \\
\text { intervention } \\
\text { completion }\end{array}$ & $\begin{array}{l}\text { - For participants with TBI, } \\
\text { greater within group } \\
\text { changes were noted after } \\
\text { exergaming intervention } \\
\text { completion for both BBS } \\
(\mathrm{ES}=5.73) \text { and DASH } \\
(\mathrm{ES}=2.35) \text {. } \\
\text { - Change in BBS above } \\
\text { measurement error and } \\
\text { represents true change. }\end{array}$ \\
\hline
\end{tabular}




\begin{tabular}{|c|c|c|c|c|c|c|}
\hline $\begin{array}{l}\text { Buccalleto } \\
\text { et al. } 2020 \text {; } \\
\mathrm{n}=21(17 \\
\text { TBI) } \\
\text { DBS } 19 \\
\text { (good) }\end{array}$ & $\begin{array}{l}\text { - All participants } \\
\text { had chronic } \\
\text { injuries. } \\
\text { - Level of initial } \\
\text { injury severity } \\
\text { not provided. }\end{array}$ & $\begin{array}{l}\text { Participants } \\
\text { randomized to } \\
\text { an early ( } \mathrm{n}=11) \\
\text { or a delayed } \\
\text { treatment group } \\
\text { ( } \mathrm{n}=10 ; \text { training } \\
3 \text { weeks after } \\
\text { study initiation). } \\
\text { The } \\
\text { BrightBrainer } \\
\text { system was used } \\
\text { to perform } \\
\text { exergames. }\end{array}$ & $\begin{array}{l}\text { All participants started } \\
\text { with unimanual games } \\
\text { and then progressed to } \\
\text { playing bimanual } \\
\text { games using handheld } \\
\text { controllers. } \\
\text { Games trained } \\
\text { cognitive and motor } \\
\text { aspects of movements. }\end{array}$ & $\begin{array}{l}\text { FMA, BBT and } \\
\text { Jebsen Taylor Hand } \\
\text { Function Test. }\end{array}$ & $\begin{array}{l}\text { - Baseline and } \\
\text { intervention } \\
\text { completion }\end{array}$ & $\begin{array}{l}\text { - No change seen in FMA or } \\
\text { BBT scores. } \\
\text { - Improved scores on the } \\
\text { Jebsen Taylor test for both } \\
\text { groups after intervention } \\
(\mathrm{ES}=0.52) \text {. } \\
\text { - Change in BBS above } \\
\text { measurement error and } \\
\text { represents true change. }\end{array}$ \\
\hline
\end{tabular}

DBS: Downs and Black Checklist Score; TBI: Traumatic Brain Injury; PTA: Post Traumatic Amnesia; UL: Upper Limb; FMA: Fugl Meyer Assessment; BBT: Box and Blocks Test; ES: Effect Size 
Table 4. Use of Noninvasive Stimulation and Arm Ability Training

\begin{tabular}{|c|c|c|c|c|c|c|}
\hline $\begin{array}{c}\text { Study; } \\
\text { Sample size } \\
\text { (n), } \\
\text { Down's and } \\
\text { Black score }\end{array}$ & $\begin{array}{l}\text { Chronicity and } \\
\text { severity of } \\
\text { injury }\end{array}$ & $\begin{array}{c}\text { Intervention } \\
\text { details }\end{array}$ & $\begin{array}{l}\text { Rehabilitation } \\
\text { provided/Dose }\end{array}$ & Outcomes & $\begin{array}{c}\text { Timing of } \\
\text { assessment }\end{array}$ & Results \\
\hline \multicolumn{7}{|c|}{ A. Use of NeuroMuscular Electrical Stimulation } \\
\hline $\begin{array}{l}\text { Alon et al. } \\
1998 ; \\
\mathrm{n}=20(7 \\
\text { TBI) } \\
\text { DBS = } 17 \\
\text { (fair) }\end{array}$ & $\begin{array}{l}\text { - All } \\
\text { participants } \\
\text { had chronic } \\
\text { injuries } \\
\text { - Initial injury } \\
\text { severity level } \\
\text { information } \\
\text { missing }\end{array}$ & $\begin{array}{l}\text { Provision of } \\
\text { NMES enabling } \\
\text { reciprocal finger } \\
\text { flexion and } \\
\text { extension along } \\
\text { with grasp and } \\
\text { release. }\end{array}$ & $\begin{array}{l}\text { Forearm-hand splint } \\
\text { with surface } \\
\text { electrodes positioned } \\
\text { over the wrist and } \\
\text { hand muscles. } \\
\text { Pulses delivered in } \\
\text { an interrupted mode; } \\
\text { contraction and } \\
\text { relaxation intervals: } \\
\text { 3-7 secs } \\
\text { Daily average of } 3.5 \\
\text { hrs stimulation for a } \\
\text { total of } 4 \text { mos. }\end{array}$ & $\begin{array}{l}\text { Resting postures, } \\
\text { active, and passive } \\
\text { ROM at the wrist } \\
\text { and elbow joints } \\
\text { assessed using } \\
\text { goniometry at the } \\
\text { beginning and end } \\
\text { of the intervention }\end{array}$ & $\begin{array}{l}\text { - Baseline } \\
\text { and after } \\
\text { intervention } \\
\text { completion }\end{array}$ & $\begin{array}{l}\text { Wrist Joint } \\
\text { - } \text { More extended resting } \\
\text { posture (ES = 3.71) at the } \\
\text { intervention completion. } \\
\text { - Increased range of passive } \\
(\mathrm{ES}=2.69) \text { as well as } \\
\text { active extension (ES = } \\
\text { 2.73) } \\
\qquad \text { Elbow Joint } \\
\text { - More extended resting } \\
\text { posture (ES = 4.09) at the } \\
\text { intervention completion. } \\
\text { - Increase in active elbow } \\
\text { extension ROM (ES = 6.91) }\end{array}$ \\
\hline \multicolumn{7}{|c|}{ B. Use of Transcranial Direct Current Stimulation } \\
\hline $\begin{array}{l}\text { Kang et al } \\
2012 ; \\
\mathrm{n}=9 \\
\text { DBS = } 18 \\
\text { (fair) }\end{array}$ & $\begin{array}{l}\text { - Participants } \\
\text { had either } \\
\text { sub-acute (n } \\
=4) \text { or } \\
\text { chronic ( } \mathrm{n}= \\
\text { 5) injuries. } \\
\text { - Initial injury } \\
\text { severity }\end{array}$ & $\begin{array}{l}\text { Real }(2 \mathrm{~mA} \\
\text { anodal) or sham } \\
\text { stimulation }\end{array}$ & $\begin{array}{l}\text { tDCS stimulation } \\
\text { over DLPFC applied } \\
\text { for } 20 \text { minutes. } \\
\text { Sham stimulation } \\
\text { consisted of } 1 \mathrm{~min} \\
\text { ramp up and ramp } \\
\text { down. }\end{array}$ & $\begin{array}{l}\text { Reaction time on } \\
\text { Contrast reaction } \\
\text { time task }\end{array}$ & $\begin{array}{l}\text { - Baseline, } \\
\text { immediately } \\
\text { after } \\
\text { intervention } \\
\text { completion, } 3 \\
\text { hrs and } 24 \mathrm{hrs} \\
\text { after } \\
\text { intervention } \\
\text { completion. }\end{array}$ & $\begin{array}{l}\text { - Tendency }(\mathrm{p}=0.056) \text { to } \\
\text { reduce reaction time after } \\
\text { real compared to sham } \\
\text { stimulation; ES }=0.89 \text {. } \\
\text { - This change was not } \\
\text { maintained } 3 \text { hours post } \\
\text { stimulation }(\mathrm{ES}=0.1) \text {. }\end{array}$ \\
\hline
\end{tabular}




\begin{tabular}{|c|c|c|c|c|c|c|}
\hline & $\begin{array}{l}\text { level } \\
\text { information } \\
\text { missing. }\end{array}$ & & & & $\begin{array}{l}\text { - MMSE scores } \\
\text { assessed only } \\
\text { at baseline. }\end{array}$ & $\begin{array}{l}\text { However, better retention } \\
\text { of change in reaction times } \\
24 \text { hours post stimulation } \\
(\mathrm{ES}=0.96) \text { and this change } \\
\text { correlated moderately with } \\
\text { initial MMSE scores }(\mathrm{r}= \\
0.67)\end{array}$ \\
\hline $\begin{array}{l}\text { Middleton et } \\
\text { al 2014; } \\
\mathrm{n}=5(2 \mathrm{TBI}) \\
\mathrm{DBS}=14 \\
\text { (fair) }\end{array}$ & $\begin{array}{l}\text { - Both } \\
\text { participants } \\
\text { had chronic } \\
\text { injuries } \\
\text { - Initial injury } \\
\text { severity level } \\
\text { information } \\
\text { missing }\end{array}$ & $\begin{array}{l}\text { Bihemispheric } \\
\text { stimulation of } \\
1.5 \mathrm{~mA} \text { for } 20 \\
\text { minutes. } \\
\text { Total of } 24 \\
\text { sessions, } \\
\text { sessions held } \\
\text { thrice weekly. }\end{array}$ & \begin{tabular}{|l|} 
Stimulation followed \\
by intensive task- \\
specific practice of \\
UL gross and fine \\
motor activities. \\
Gross motor activities \\
- reaching for items \\
on shelves, hitting a \\
balloon with a racquet \\
and simulating \\
household chores. \\
Fine motor activities - \\
flipping playing cards \\
and manipulating \\
small change.
\end{tabular} & $\begin{array}{l}\text { Clinical: FMA and } \\
\text { BBT } \\
\text { Kinematic: } \\
\text { Movement } \\
\text { straightness and } \\
\text { speed assessed } \\
\text { using the robotic } \\
\text { manipulandum. } \\
\text { Assessments } \\
\text { completed } \\
\text { immediately after } \\
\text { practice and at 6- } \\
\text { month retention } \\
\text { assessment. }\end{array}$ & $\begin{array}{l}\text { - Baseline, } \\
\text { immediately } \\
\text { after } \\
\text { intervention } \\
\text { completion, } \\
\text { and } 6 \text { mos. } \\
\text { after } \\
\text { intervention } \\
\text { completion }\end{array}$ & $\begin{array}{l}\text { In participants with TBI- } \\
\text { - Intervention led to better } \\
\text { FMA scores (ES }=0.47) \text {, } \\
\text { which was retained (ES = } \\
0.42) \text {. } \\
\text { - Change in FMA scores } \\
\text { exceeded MCID levels. } \\
\text { - All participants moved faster } \\
(\mathrm{ES}=0.37) . \text { At retention, } \\
\text { participants continued to } \\
\text { move faster }(\mathrm{ES}=0.70) \text {. }\end{array}$ \\
\hline \multicolumn{7}{|c|}{ C. Use of Arm Ability Training } \\
\hline $\begin{array}{l}\text { Platz et al. } \\
2001 ; \\
\mathrm{n}=60(15 \\
\text { TBI) } \\
\begin{array}{l}\text { DBS }=25 \\
\text { (excellent) }\end{array}\end{array}$ & $\begin{array}{l}\text { - Participants } \\
\text { had acute to } \\
\text { early chronic } \\
\text { injuries ( } 3 \\
\text { wks - } 24 \\
\text { mos.) post } \\
\text { injury. } \\
\text { - Initial injury } \\
\text { severity level } \\
\text { information } \\
\text { missing }\end{array}$ & $\begin{array}{l}\text { Participants } \\
\text { randomized into } \\
\text { groups to received } \\
\text { Arm Ability } \\
\text { Training, Ability } \\
\text { Training with } \\
\text { knowledge of } \\
\text { results feedback or } \\
\text { no Arm Ability } \\
\text { Training ( } \mathrm{n}=20 \\
\text { each). }\end{array}$ & $\begin{array}{l}\text { Arm Ability Training } \\
\text { included activities } \\
\text { involving dexterity } \\
\text { manipulation, aiming } \\
\text { for targets and gripping } \\
\text { objects of different } \\
\text { sizes. } \\
\text { The knowledge of } \\
\text { results feedback group } \\
\text { got average feedback. }\end{array}$ & $\begin{array}{l}\text { Clinical: Hand } \\
\text { function evaluated } \\
\text { using the Test } \\
\text { Evaluant les } \\
\text { Membres superieurs } \\
\text { des Personnes Agees } \\
\text { (TEMPA). } \\
\text { Kinematic: } \\
\text { Movement time for } \\
\text { aiming movements }\end{array}$ & $\begin{array}{l}\text { - Baseline, } \\
\text { intervention } \\
\text { completion } \\
\text { and one year } \\
\text { after } \\
\text { intervention } \\
\text { completion. }\end{array}$ & $\begin{array}{l}\text { TEMPA } \\
\text { - Participants who received } \\
\text { Arm Ability Training took } \\
\text { less time to complete the } \\
\text { TEMPA }(\mathrm{ES}=0.95) \text { at } \\
\text { intervention completion. } \\
\text { - Changes were retained at } \\
\text { one year }(\mathrm{ES}=0.82) \text {. } \\
\text { Kinematic outcomes }\end{array}$ \\
\hline
\end{tabular}




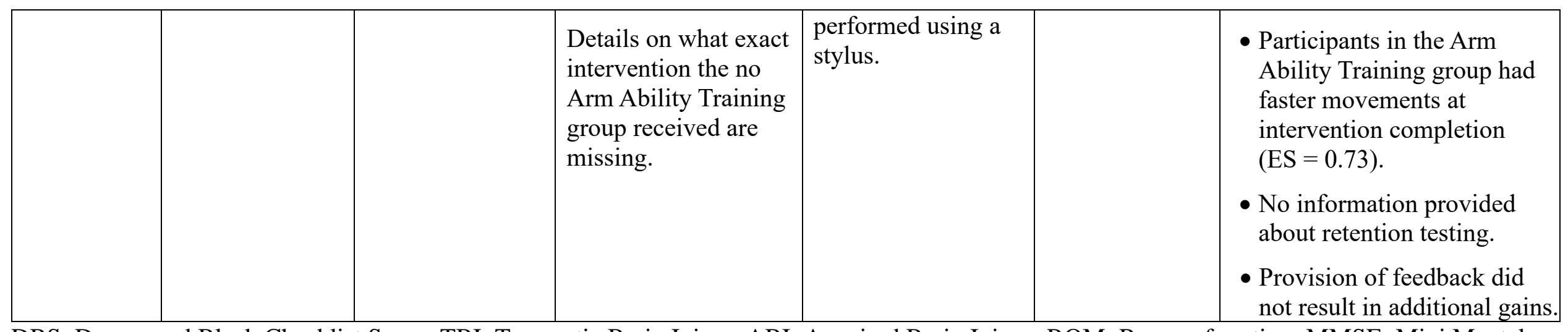

DBS: Downs and Black Checklist Score; TBI: Traumatic Brain Injury; ABI: Acquired Brain Injury; ROM: Range of motion; MMSE: Mini Mental Scale Examination; FMA: Fugl Meyer Assessment; BBT: Box and Blocks Test; ES: Effect Size; MCID: Minimal Clinically Important Difference 
Table 5: Use of Stem cells and other interventions

\begin{tabular}{|c|c|c|c|c|c|c|}
\hline $\begin{array}{c}\text { Study; } \\
\text { Sample size } \\
\text { (n), } \\
\text { Down's and } \\
\text { Black score }\end{array}$ & $\begin{array}{c}\text { Chronicity and } \\
\text { severity of } \\
\text { injury }\end{array}$ & $\begin{array}{c}\text { Intervention } \\
\text { details }\end{array}$ & $\begin{array}{l}\text { Rehabilitation } \\
\text { provided/Dose }\end{array}$ & Outcomes & $\begin{array}{c}\text { Timing of } \\
\text { assessment }\end{array}$ & Results \\
\hline \multicolumn{7}{|c|}{ A. Stem cell transplantation } \\
\hline $\begin{array}{l}\text { Wang et al. } \\
2013 ; \\
\mathrm{n}=40 \\
\text { DBS = } 18 \\
\text { (fair) }\end{array}$ & $\begin{array}{l}\text { - All } \\
\text { participants } \\
\text { had chronic } \\
\text { injuries } \\
\text { - All } \\
\text { participants } \\
\text { had severe } \\
\text { injuries } \\
\text { (mean GCS } \\
\text { score of 7). }\end{array}$ & $\begin{array}{l}\text { Participants were } \\
\text { randomized into } \\
\text { two groups to } \\
\text { receive stem cells } \\
\text { or a control group. } \\
\text { The stem cell group } \\
\text { received an } \\
\text { injection of } \\
\text { umbilical cord } \\
\text { mesenchymal stem } \\
\text { cells. } \\
2 \text { ml of stem cell } \\
\text { suspension } \\
\text { (containing } 1 * 10^{7} \\
\text { stem cells) injected } \\
\text { into subarachnoid } \\
\text { space between } \\
\text { lumbar vertebrae } 3 \\
\text { and } 4 \text { or } 4 \text { and } 5 \text {. }\end{array}$ & $\begin{array}{l}\text { Details on whether } \\
\text { the intervention or } \\
\text { control group } \\
\text { received any form of } \\
\text { rehabilitation are } \\
\text { missing. }\end{array}$ & FMA and FIM. & $\begin{array}{l}\text { - Baseline and } \\
6 \text { mos. post } \\
\text { injection }\end{array}$ & $\begin{array}{l}\text { - Significant improvement in } \\
\text { upper }(\mathrm{ES}=1.38) \text { and lower } \\
\text { limbs }(\mathrm{ES}=0.88) \text { FMA } \\
\text { scores as well as FIM } \\
\text { scores }(\mathrm{ES}=1.17) \text { for the } \\
\text { intervention group. } \\
\text { - No change seen in control } \\
\text { group. }\end{array}$ \\
\hline \multicolumn{7}{|c|}{ B. Other Interventions } \\
\hline $\begin{array}{l}\text { Sietsema et } \\
\text { al. } 1993 ; \\
\mathrm{n}=20 \\
\begin{array}{l}\mathrm{DBS}=18 \\
\text { (fair) }\end{array}\end{array}$ & $\begin{array}{l}\text { - All } \\
\text { participants } \\
\text { had chronic } \\
\text { injuries }\end{array}$ & $\begin{array}{l}\text { Computer game } \\
\text { involving reaching } \\
\text { from a seated } \\
\text { position or rote arm } \\
\text { reaching. }\end{array}$ & $\begin{array}{l}\text { Initially, NDT based } \\
\text { intervention was } \\
\text { provided. } \\
\text { Participants performed } \\
\text { rote reaching exercises }\end{array}$ & $\begin{array}{l}\text { Reaching distance } \\
\text { between hip and } \\
\text { wrist measured } \\
\text { using a motion } \\
\text { capture system }\end{array}$ & $\begin{array}{l}\text { - Baseline and } \\
\text { after } 10 \\
\text { trials in each } \\
\text { condition }\end{array}$ & $\begin{array}{l}\text { - Greater reaching distance } \\
\text { over the } 10 \text { trials of playing } \\
\text { the game compared to rote } \\
\text { reaching }(\mathrm{ES}=1.41) \text {. }\end{array}$ \\
\hline
\end{tabular}




\begin{tabular}{|c|c|c|c|c|c|c|}
\hline & $\begin{array}{l}\text { - All } \\
\text { participants } \\
\text { had mild to } \\
\text { moderate } \\
\text { injuries } \\
\text { (RLA } \\
\text { staging score } \\
\text { IV or V). }\end{array}$ & & $\begin{array}{l}\text { or played a computer } \\
\text { game. } \\
\text { The game involved } \\
\text { repeating a sequence } \\
\text { of flashing lights and } \\
\text { sounds by pressing } \\
\text { certain buttons. } \\
\text { The order of playing } \\
\text { the game or rote arm } \\
\text { reaching was } \\
\text { counterbalanced. }\end{array}$ & & & \\
\hline $\begin{array}{l}\text { Croce et al. } \\
1996 ; \\
\mathrm{n}=51 \\
\text { DBS = } 18 \\
\text { (fair) }\end{array}$ & $\begin{array}{l}\text { - All } \\
\text { participants } \\
\text { had chronic } \\
\text { injuries } \\
\text { - All } \\
\text { participants } \\
\text { had moderate } \\
\text { injuries (GCS } \\
\text { score: } 8-12) .\end{array}$ & $\begin{array}{l}\text { Practice of an } \\
\text { anticipation task that } \\
\text { involved pressing a } \\
\text { button when they } \\
\text { saw the last light. }\end{array}$ & $\begin{array}{l}\text { Participants divided } \\
\text { into } 4 \text { groups } \\
\text { depending upon when } \\
\text { they received } \\
\text { Knowledge of Results } \\
(\text { KR) feedback into a } \\
\text { no KR group }(\mathrm{n}=12) \text {, } \\
100 \% \text { KR }(\mathrm{n}=14) \text {, } \\
\text { summary KR (after } \\
\text { every } 5 \text { trials; } \mathrm{n}=13) \\
\text { and average KR } \\
\text { (average information } \\
\text { for all } 5 \text { trials; } \mathrm{n}=12) \\
\text { Individuals } \\
\text { performed } 60 \\
\text { acquisition trials }(12 \\
\text { blocks of } 5 \text { trials } \\
\text { each). }\end{array}$ & $\begin{array}{l}\text { Absolute error in } \\
\text { terms of timing of } \\
\text { responses. }\end{array}$ & $\begin{array}{l}\text { - Assessments } \\
\text { conducted at } \\
\text { intervention } \\
\text { completion, } \\
\text { ten minutes } \\
\text { after the last } \\
\text { acquisition } \\
\text { trial, } \\
\text { (immediate } \\
\text { retention) } \\
\text { and } 24 \text { hrs } \\
\text { following } \\
\text { the last } \\
\text { acquisition } \\
\text { trial (late } \\
\text { retention). }\end{array}$ & $\begin{array}{l}\text { - Provision of KR better than } \\
\text { no KR. } \\
\qquad 100 \% \text { KR } \\
\text { - Effective immediately after } \\
\text { practice; ES = 0.96. } \\
\text { - Effects reduced at } \\
\text { immediate retention testing; } \\
\text { ES =0.67 and at late } \\
\text { retention; ES = } 0.37 \\
\qquad \text { Summary KR } \\
\text { - Beneficial immediately after } \\
\text { practice; ES = 0.97. } \\
\text { - Changes maintained at } \\
\text { immediate and late retention } \\
\text { periods; ES = 1.21. } \\
\qquad \text { Average KR } \\
\text { - Beneficial immediately after } \\
\text { practice; ES = 0.95. } \\
\text { - Changes maintained at early } \\
\text { retention; ES = 1.02; but } \\
\text { declined at late retention; } \\
\text { ES = 0.77. }\end{array}$ \\
\hline
\end{tabular}




\begin{tabular}{|c|c|c|c|c|c|c|}
\hline $\begin{array}{l}\text { Sterr and } \\
\text { Freigvogel, } \\
2003 ; \\
\mathrm{n}=13(11 \\
\mathrm{TBI}) \\
\begin{array}{l}\text { DBS }=18 \\
\text { (fair) }\end{array}\end{array}$ & $\begin{array}{l}\text { - All } \\
\text { participants } \\
\text { had chronic } \\
\text { injuries } \\
\text { - Initial injury } \\
\text { severity } \\
\text { level } \\
\text { information } \\
\text { missing }\end{array}$ & Forced use therapy. & $\begin{array}{l}\text { All participants } \\
\text { initially received OT } \\
\text { for } 90 \text { minutes for } 4 \\
\text { weeks in phase A. } \\
\text { This was followed by } \\
\text { forced use therapy } \\
\text { involving principles } \\
\text { of shaping for } \\
\text { another } 4 \text { weeks in } \\
\text { phase B. } \\
\text { The participants } \\
\text { practiced } 4-10 \text { tasks } \\
\text { in each session. }\end{array}$ & $\begin{array}{l}\text { The Frenchay Arm } \\
\text { Test; MAL AoU, } \\
\text { MAL QoM as well } \\
\text { as WMFT-FAS }\end{array}$ & $\begin{array}{l}\text { - At the end of } \\
\text { phases A and } \\
\text { B, and one } \\
\text { month after } \\
\text { the end of } \\
\text { Phase B. }\end{array}$ & $\begin{array}{l}\text { Immediately at the end of } \\
\text { Phase B: } \\
\text { - Significant improvements } \\
\text { seen in Frenchay Arm Test } \\
\text { scores (ES =0.72), MAL } \\
\text { AoU (ES = 2.38), MAL } \\
\text { QoM (ES = 1.98) and } \\
\text { WMFT-FAS (ES = 1.76). } \\
\text { - Change in MAL AoU and } \\
\text { QoM scores at MCID level. } \\
\text { Retention at } 4 \text { weeks post } \\
\text { practice: } \\
\text { - Changes were not retained } \\
\text { compared to end of Phase A } \\
\text { in any of the } 4 \text { clinical } \\
\text { outcomes. }\end{array}$ \\
\hline
\end{tabular}

DBS: Downs and Black Checklist Score; GCS: Glasgow Coma Scale; FMA: Fugl Meyer Assessment; FIM: Functional Independence Measure; ABI: Acquired Brain Injury; KR: Knowledge of Results; WMFT-FAS: Wolf Motor Function Test - Functional Assessment Scale; OT: Occupational Therapy; MAL-QoM : Motor Activity Log Quality of Movement; MAL-AoU: Motor Activity Log Amount of Use; ES: Effect Size ES: Effect Size; MCID: Minimal Clinically Important Difference 
Records identified through

database searching

$(n=135)$
Additional records identified

through reference lists
Records after duplicates removed

$$
(n=120)
$$

Records screened

$$
(n=120)
$$

Full-text articles assessed for eligibility

$$
(n=30)
$$

